\title{
Regionális különbségek és árkonvergencia a visegrádi országok termőföldpiacán*
}

\section{Sőreg Ádám Pál \\ mezőgazdasági vállalkozó, a Szent István Egyetem PhD-hallgatója \\ E-mail: adam.soereg@gmail.com}

\section{Noár Antal Tamás,}

a GAK Nonprofit Közhasznú Kft. üzemeltetési igazgatója, a Szent István Egyetem PhD-hallgatója

E-mail: naaratamas@gmail.com

\section{Naórné Tóth Zsuzsanna,}

a Szent István Egyetem egyetemi docense

E-mail:

Toth.Zsuzsanna@gtk.szie.hu
Csaknem tizenhárom évvel a visegrádi országok európai uniós csatlakozása után továbbra is nyitott kérdés, hogy az új (2004 után csatlakozó) és a régi tagállamok földpiaca között a jövőben megvalósulhate teljes árkonvergencia. Az elmúlt másfél évtizedben a kelet-európai tagállamok termőföldpiacát a régi EUtagok belső piacához képest élénkebb földforgalom és a piaci árak dinamikusabb emelkedése jellemezte. Jelen tanulmány e tendencia mozgatórugóinak feltárását és részletes elemzését tűzi ki célul. Bemutatja a visegrádi országok mezőgazdasági termelési struktúráit, valamint a földforgalmi szabályozás sajátosságainak és a helyi makrogazdasági tendenciáknak a hatásait a termőföld mint erőforrás piaci árának alakulására. A szerzők az országos változások és a mögöttes okok elemzésén túl a regionális, illetve a megyei/tartományi szinten mutatkozó markáns értékkülönbségek magyarázatára is kísérletet tesznek. Tekintettel arra, hogy a termőföld kereslete és kínálata is erősen helyhez kötött, a térségi árkülönbségeket egy, az agrárszektor és a teljes gazdasági vertikum lokális fejlettségét kifejező mutatókból álló, többváltozós lineáris regressziós modell segítségével vizsgálják.

\section{TÁRGYSZÓ:}

Termőföld.

Visegrádi országok.

Árkonvergencia.

DOI: $10.20311 /$ stat2017.04.hu0349

* A tanulmány az Emberi Erőforrások Minisztériuma ÚNKP-16-4 kódszámú Új Nemzeti Kiválóság Programjának támogatásával készült. 
A földnek (mint a mezőgazdasági termelés alapjának és forrásának) valamennyi termelőeszköz között kiemelkedő a szerepe; tulajdoni és használati jogának, értékének, illetve piaci árának kérdése a gazdasági, társadalmi és politikai döntések egyik kulcsproblémája. Napjainkban e természeti erőforrás gazdasági értékének kérdése nemcsak az Európai Unió régi (2004 előtt csatlakozott) tagállamainak körében merül fel (elsődlegesen a felelős földgazdálkodással, a környezetvédelmi szempontokkal és a piaci verseny éleződése miatt megkívánt, hatékony földhasznosítással kapcsolatos elvárások miatt), hanem az 1980-as évtized végén és az 1990-es évek első éveiben rendszert váltó új tagállamokban is. Hazánkban az elmúlt évtizedben több tényező is aktuálissá tette a föld közgazdasági értékének vizsgálatát. Ezek közül a legfontosabb az volt, hogy a szocialista gazdasági rendszer kollektivizált, szövetkezeti alapon termelő mezőgazdaságán belül nem került sor kellő számban bérleti vagy adásvételi tranzakciókra; így müködő földpiac hiányában valós piaci érték sem alakult ki, ami miatt a különféle módszerekkel megállapított árak napjainkban (például hitelfedezet szempontjából) nem vehetők alapul (Naárné [2009]).

Jelenleg nincs az EU-nak egy egységesen alkalmazott, általánosan elfogadott földértékelési módszere (Naárné [2009]). Egyes tagországok az amerikai modellt, míg mások attól és/vagy egymástól is eltérö nemzeti hagyományokat követnek. Az amerikai földértékelési módszer (USDA LCC [U.S. Department of Agriculture Land capability classification - az Egyesült Államok Mezőgazdasági Minisztériumának termőképességi osztályozása]) egy hierarchikus, háromszintű osztályozás: termőképességi osztályokat, alosztályokat, egységeket különböztet meg. A korlátozás mértéke szerint a talaj-felvételezési egységeket nyolc minőségi osztályba sorolja. Az első négy a szántóföldi növénytermesztésre alkalmas területeket osztályozza négy részkategóriára bontva, míg az 5-8. minőségi osztályok azokat a területeket, amelyek növénytermesztésre alkalmatlanok.

Az USDA LCC nem merev rendszernek, inkább csak keretnek tekinthető, amelyet változatlan vagy módosított formában számos országban használnak (Patocskai [2012]). Bevezetése elött azonban már több helyen törvénybe foglaltak más, egyszerü felépítésű, paraméter-rendszerü talajbecslési eljárásokat is. Ilyen volt például az Egyesült Államokban a Storie-index (Storie [1933]), Németországban a régi birodalmi talajbecslés (Bastian-Schreiber [1999]) és Magyarországon, mindkettőt megelőzve, az 1848-as forradalmat követő évtizedekben kidolgozott és bevezetett aranykorona-rendszer, ami alapvetően gazdasági megközelítésű és egyetlen komplex paramétert alkalmaz. 


\section{A termőföld mint erőforrás közgazdasági értéke}

A föld értékelése összetett feladat, mely átfogja a termőföld ökológiai minősítését és (köz)gazdasági értékelését. Szücs [2003] a földértékelés módszereit az amerikai szakirodalmi ajánlások alapján a következőképpen különíti el.

- Az adásvételi értékek piaci összehasonlitásán alapuló módszer akkor használható, ha megfelelő ismeretünk van a szóban forgó földterület piaci környezetéről. A módszer alapját a hasonló fizikai és kémiai tulajdonságú, természetes termékenységü, tőkeértékü, útviszonyokkal rendelkezö, infrastrukturális ellátottságú, ipari vagy településközpontok környékén levő stb. területek tényleges piaci árai képezik. Aktuális árak hiányában és a termőföld alacsony forgási sebessége esetén a korábbi évek adásvételi tranzakciói jelenthetik az alapot. A tényleges ár meghatározásánál ilyenkor a tranzakciós árakat az időközben bekövetkezett gazdasági-piaci változások és azok (például inflációs) hatásainak mérlegelésével lehet figyelembe venni.

- Értékmegosztáson alapuló földértékelést általában akkor használnak, ha a piaci forgalom túl alacsony ahhoz, hogy az a földterület árára vonatkozóan információkat szolgáltasson. A módszer az ingatlanok, azaz a felépítmény és a földterület együttes piaci árából indul ki, amit a földre épített objektumok értékével (az épületek, létesítmények fenntartásából származó járadéksorozat jelenértékével) korrigálnak.

- A tervezéses módszer a föld értékét a beépítésre került telek árából vezeti le, levonva abból a fejlesztések nettó értékét. Ez az eljárás akkor használható, ha a parcellázás utáni fejlesztés jelenti az adott földterület legkedvezőbb hasznosítását, és hasonló telkekről már vannak piaci információk. Az értékelési munka a lehetséges parcellák kialakításának tervezésével kezdődik.

- A föld maradék értékének számitásán alapuló értékelési technika piaci információk hiányában alkalmazható abban az esetben, ha van elegendő ismeretünk az ingatlan használatából származó teljes nettó jövedelemről. A számítás menete a következő: a teljes építményérték és a telek külön-külön elvárt tőkehozadékának, majd a földnek tulajdonítható jövedelemrész meghatározása, amiből tőkésítési módszerrel történik a föld árának becslése. A módszer alapelve az, hogy a földjáradékot maradványértékként határozza meg, tehát az összes jövedelemből levonja a munkaerő és a nem földalapú tőke hozadékát.

- A földbérleti dij tökésitésekor abból indulnak ki, hogy a piaci körülmények között kialakult bérleti díj elfogadható pontossággal fejezi 
ki a föld jövedelemtermelő képességét, megfelel a föld mint termelési tényező közgazdasági értelemben vett használati díjának. A bérleti díjak sorozatának tőkésített (piaci kamatlábbal diszkontált) értéke megközelítőleg az adott földterület piaci árának felel meg.

Az egyes országokban rendszeresített földértékelési eljárások céljaikat és az alkalmazott módszereket tekintve meglehetősen eltérőek. Az EU tagországaiban használt értékelési rendszereket áttekintve (Naárné [2006], [2009]) megállapítható, hogy a termőföld-értékelés szabályozása tagállami hatáskörben maradt, európai uniós szintű egységesítésére még nem voltak törekvések.

Az utóbbi évtizedekben a világgazdaság fejlett országaiban megfigyelhető volt mind a jövedelmek, mind a tőkejavak formájában felhalmozott vagyon koncentrációja. A második világháború óta nem voltak olyan magasak a jövedelmi és a vagyoni egyenlőtlenségek mérőszámai, mint napjainkban, hasonló nagyságrendü különbségek utoljára a XIX. és a XX. század fordulóján jelentkeztek a fejlett piacgazdasággal rendelkező országokban (Piketty [2014]). A mezögazdaságban a földbirtokok és az egyéb termelöeszköz-állomány esetében a világgazdaság más ágazataihoz hasonló folyamatokat figyelhetünk meg. Nemzetközi tendenciák azt mutatják, hogy az elmúlt évtizedek birtokkoncentrációja nem földvásárlással, inkább földbérléssel ment végbe, azaz a termelőeszközök növekvő koncentrációjában a használati jog meghatározóbb szerepet játszik/játszott a tulajdonjognál. Ez a jelenség arra vezethető vissza, hogy NyugatEurópában (és a fejlett világ más részein is) egyre kevesebb a megvásárolható földterület, a földpiac szükös és rugalmatlan kínálati viszonyai mellett az árak hosszú távon emelkednek, és emiatt a tulajdonosok nem szívesen válnak meg földtulajdonuktól, mivel azt értékálló vagyontárgynak tekintik. Sok esetben a mezőgazdasági vállalkozók számára is kedvezőbb ez a forma, hiszen a rendelkezésre álló bérleti konstrukciókkal kisebb tőkebefektetés mellett növelhető a birtoknagyság, s a terjeszkedéshez kapcsolódó gazdasági-pénzügyi kockázatok is alacsonyabbak. A földbérleti szerződés megkötésével a gazda számára elkerülhetô a hitelfelvétel, a vásárláshoz szükséges önrész pedig más eszközökbe, például modern gépekbe és precíziós technológiába forgatható vissza.

A közgazdasági megközelítés szerint a föld - akár a bolygófelszín tágabb értelemben vett szárazföldi területeinek véges kínálatát, akár a szükebb értelemben vett, mezőgazdasági tevékenység folytatására alkalmas termőterületet értjük alatta - a termelési tényezők körébe sorolható erőforrás. Miközben valamennyi termelési tényezőről elmondható, hogy keresletük származékos, a végső fogyasztás céljára előállított termékek és szolgáltatások keresletének függvénye, addig a föld piaca és ezáltal a földterületek árazódása is számos különleges tulajdonságot tudhat magáénak.

A föld kínálata alapvetően rugalmatlan, hiszen a világon véges mennyiségben áll rendelkezésre, csupán a különböző használati (mezőgazdasági, lakhatási, ipari és szolgáltató, rekreációs, erdőgazdálkodási és természetvédelmi stb.) célokra lekö- 
tött területek aránya változtatható. Emiatt a fejlett országokban több évtizedes távlatban összefüggés mutatható ki az épített ingatlanok és a föld ára között, hiszen a „földárkomponens” az előbbi értékébe is beépül (Knoll-Schularick-Steger [2015]). A földpiac helyzetét tovább bonyolítja, hogy a föld kínálati korlátja nemcsak globális szinten, hanem lokálisan is jelentkezik; bármely földterület helyhez kötött, így az arra irányuló kereslet azoktól a gazdasági szereplőktől függ, akik adott technikai színvonal, illetve szállítási és közlekedési költségszint mellett elérhető távolságban helyezkednek el a kérdéses területtől (Szücs [1998] 10-12. old.). A föld alternatív hasznosítását emellett helyi sajátosságok is korlátozhatják (például egy meredek hegyoldal, ha megfelelő adottságokkal rendelkezik, bortermelésre, erdőgazdálkodásra vagy legeltetésre is használható, de nem folytatható rajta gazdaságosan szántóföldi növénytermesztés, és építési célra is alkalmatlan). Végül a föld értékének alakulása szempontjából azt is fontos figyelembe venni, hogy e termelési tényező értéke nem csökken idővel. A mezőgazdasági földterületek vizsgálata során viszont azzal is számolni kell, hogy a termőréteg csak rendeltetésszerü használat, okszerü mezőgazdasági tevékenység folytatása mellett nem amortizálódik. Egy erózió vagy szennyezés által károsított terület csak jelentős, esetenként meg nem térülő ráfordítással állítható helyre, természetes regenerációjához hosszú évtizedek vagy évszázadok szükségesek. Mindezek egyenes következménye a föld mint erőforrás alacsony forgási sebessége és a földpiac korlátozott tranzakciószáma, amely megnehezíti a földvagyon közgazdasági megközelítésủ értékelését. Termőföldet általában csak a helyben müködő egyéni és társas mezőgazdasági vállalkozások, építésre alkalmas területet pedig az esetek döntő többségében helyi lakók és helyi érdekeltségủ vállalkozók, illetve befektetők vásárolnak. Az Egyesült Királyság földpiacán például hosszú évtizedek óta a mezőgazdasági földterületek alig 1 százaléka kerül évente forgalomba (Burgerné [1997] 29. old.).

Mivel a földkínálat „rögzített”, és valamennyi gazdasági tevékenység rendelkezik helyigénnyel, a föld iránt mutatkozó kereslet alakulását alig befolyásolja az ár alakulása. A föld mint erőforrás kínálatát tehát tökéletesen, keresletét nagymértékben árrugalmatlannak tekinthetjük.

Ezzel szemben számottevő (és pozitív) a kereslet jövedelemelaszticitása, mivel a növekvő jövedelemszint emeli a makroszintü, aggregált keresletet, az pedig ösztönzi a termelési, lakhatási és rekreációs célú többletföldhasználatot, míg a jövedelmek visszaesése a földpiacon árcsökkenést vált ki (Sogaard [1993], Dovring [1987]).

Ebből adódóan a földárak nagyobb léptékủ mozgását - a rövid távú piaci ingadozásoktól eltekintve - a termőföld mint termelőeszköz hasznosításából származó nettó jövedelem, azaz a földjáradék mértéke és a termőföldalapú befektetések elvárt hozamát tükröző piaci kamatláb alakulása határozza meg. Ha a technikai haladás következtében nő a föld határtermelékenysége, illetve a korlátozott kínálathoz képest a globális népesség növekedése nyomán élénkül a kereslet, akkor a föld ára törvény- 
szerüen emelkedik. A piaci kamatláb mozgása ezzel ellentétesen hat: ha nő az elvárt hozam, a jövőben várható éves járadékok (nettó jövedelmek) jelenértéke kisebb lesz, és a földár csökken, míg alacsony kamatkörnyezetben a tőkésítési együttható növekszik, ami felértékeli a járadékok jelenértékének sorozatát, azaz a termőföld árát (Burgerné [1997] 29-30. old).

A termőföld járadékokból levezethető, $t$ időpontú (jelen)értékének általános képlete végtelen kamatozású tőke esetén:

$$
P V_{\text {föld }}=\sum_{t=1}^{\infty}\left[\left(\frac{1}{1+r}\right)^{t} J_{t}\right],
$$

ahol $t$ az egymást követő időszakok sorszáma, $J_{t}$ a termőföldből származó nettó jövedelem és a várható földalapú támogatások összege (járadék) a $t$-edik időpontban, $r$ a feltételezett kamatláb.

Amennyiben $J_{t}$ hosszú távon, a technikai haladás hatására megközelítőleg állandó növekedési rátával emelkedik, és a reálkamatok szintje azonos marad, akkor a föld értéke a $J_{0}$ jelenbeli jövedelemszint, a $\bar{g}$ növekedési ráta és az $\bar{r}$ kamatláb alapján becsülhető a mértani sor összegképletét felhasználva:

$$
P V_{\text {föld }}=\frac{J_{0}}{\bar{r}-\bar{g}} .
$$

Globális léptékben sem a mezőgazdasági területek, sem a legnagyobb súllyal elöforduló mủvelési ág, a szántó kiterjedése nem változott számottevően 1960 és 2013 között. A szántóterületek 1960 és 1985 között körülbelül 8,5 százalékkal, 1290 millió hektárról 1400 millió hektárra növekedtek, azonban a művelt szántók területe nem változott jelentősen. A világ szántóterülete 1991-ben volt a legnagyobb (1 411 millió ha), a 2009 és 2013 közötti időszak 1398 millió hektáros átlaga ettől némileg elmaradt (FAOSTAT [2016]).

Mivel 1960 és 2013 között a globális népesség évröl-évre ugyan lassuló ütemben, de folyamatosan növekedett, az egy före jutó szántóföld kiterjedése 0,42 hektárról 0,20 hektárra csökkent. (Ez is kifejezi a termőföld - és ezen belül kiemelten a szántóterületek - csaknem rögzített globális kínálatát.) Ezzel párhuzamosan, a gabonafélék termésátlaga világszinten az 1961. évi hektáronkénti 0,68 tonnáról 2013-ra közel 2 tonnára emelkedett, a Föld népessége pedig 3,1 milliárd föről 7,2 milliárd före nőtt. Ez azt jelenti, hogy a termésátlagok 53 év leforgása alatt tapasztalható 2,89-szeres emelkedése meghaladta a globális népszaporulat 2,34-szeres mértékét. (Lásd az 1. ábrát.) A nagyságrendileg állandó szántóterület mellett az egy före jutó élelmiszertermelés így a mezőgazdasági termelési technológia fejlődésének következtében - növekedni tudott. 
A magasabb termésátlagok az egységnyi kibocsátásra jutó termesztési költségek változatlansága mellett növelték/növelik az egy hektár termőföldhöz köthető nettó jövedelemszintet, és ez, mint ahogy a közgazdasági szakirodalomban régóta ismert, a föld értékének fokozatos emelkedéséhez vezet(ett) (Ricardo [1817], Burgerné [2002]).

1. ábra. A népesség, a müvelt szántóterület és a gabonafélék termésátlagának globális alakulása, 1960-2013

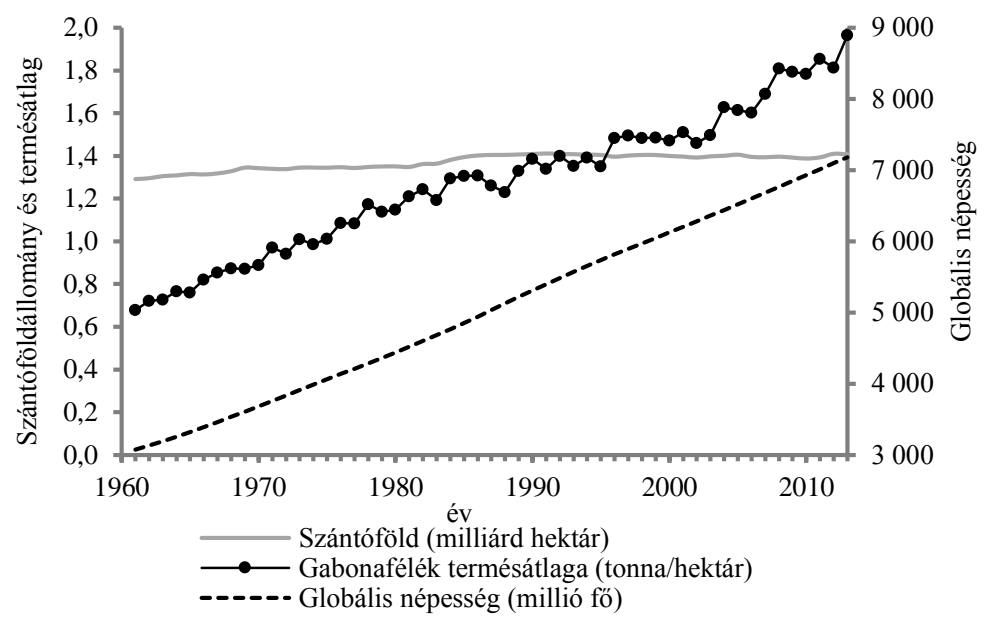

Forrás: FAOSTAT [2016] alapján saját szerkesztés.

A világviszonylatban alacsony népességük és kis földrajzi kiterjedésük következtében a visegrádi négyek (Csehország, Lengyelország, Magyarország és Szlovákia) mezőgazdasága a Föld szántóterületeinek csak 1,3 százalékát műveli, és gabonatermelésének megközelítőleg 2,5 százalékát adja. Az utóbbi évtizedekben egyre markánsabbá váló globalizációs folyamatoknak köszönhetően, a földárak visegrádi országcsoporton belüli alakulása erős összefüggést mutat a termőföldpiacon és a mezögazdasági termelési szerkezetben, illetve a technológia terén megfigyelhetö globális tendenciákkal.

\section{Földkínálat és -forgalom a visegrádi országokban}

A visegrádi országok földpiacát a négy ország mezőgazdasági mủvelés alatt álló területei adják, amelyek aránya országonként számottevő eltérést mutat: az Eurostat 2013. évi mezőgazdasági felmérése alapján Magyarország területének 50,1 százaléka, Lengyelországénak 46,1 százaléka, Csehországénak pedig 44,3 százaléka volt. 
Az ország jelentős részét borító hegyvidékek és erdők kiterjedése miatt Szlovákiában volt a legalacsonyabb, 38,8 százalék a művelt földek aránya az ország teljes területéhez képest. A visegrádi országokban így összesen 24,5 millió hektár mezőgazdasági terület található, melynek közel 60 százaléka - mintegy 14,4 millió hektár - Lengyelországban, 4,7 millió hektár Magyarországon, 3,5 millió hektár Csehországban, 1,9 millió hektár pedig Szlovákiában helyezkedik el. (Lásd az 1. táblázatot.)

1. táblázat

Mezögazdasági területek kiterjedése és megoszlása müvelési ágak szerint a visegrádi országokban, 2013

\begin{tabular}{l|r|r|r|r|r|r}
\hline \multicolumn{1}{c|}{ Ország } & \multicolumn{1}{c|}{ Összes } & Szántó & Rét/legelö & $\begin{array}{c}\text { Gyümölcs- } \\
\text { ültetvény }\end{array}$ & Szölö & Egyéb \\
\hline & \multicolumn{7}{|c}{ Kiterjedés (hektár) } \\
Lengyelország & 14409870 & 10759570 & 3206310 & 365080 & 340 & 78570 \\
\hline Csehország & 3491470 & 2492110 & 960080 & 21010 & 14850 & 3420 \\
\hline Szlovákia & 1901610 & 1363420 & 518340 & 7210 & 11230 & 1410 \\
\hline Magyarország & 4656520 & 3800820 & 702720 & 75820 & 55780 & 21380 \\
\hline & \multicolumn{7}{|c|}{ Megoszlás (\%) } \\
Lengyelország & 100,0 & 74,7 & 22,3 & 2,5 & 0,002 & 0,5 \\
\hline Csehország & 100,0 & 71,4 & 27,5 & 0,6 & 0,4 & 0,1 \\
\hline Szlovákia & 100,0 & 71,7 & 27,2 & 0,4 & 0,6 & 0,1 \\
\hline Magyarország & 100,0 & 81,6 & 15,1 & 1,6 & 1,2 & 0,5 \\
\hline
\end{tabular}

Megjegyzés. A 2. táblázat megoszlásadatai kerekítés miatt nem adják ki a 100,0 százalékot.

Forrás: Eurostat [2016] alapján saját szerkesztés.

A legfontosabb müvelési ág a visegrádi országok körében a szántó, melynek aránya Magyarországon közelítőleg 10 százalékponttal magasabb, míg a rété/legelöé viszont kisebb, mint a többi országban. Érdemes kiemelni, hogy Lengyelországban találjuk a visegrádi országok gyümölcsültetvény-állományának több mint háromnegyedét (77,8\%), míg Magyarországon a szőlőbirtokok kétharmadát (67,8\%). Az egyéb - föként faiskolák, szabadföldi és növényházas kertészetek hasznosításában levő - területek aránya Lengyelországban és Magyarországon is nagyobb a másik két országhoz képest.

A visegrádi országok termőföldpiacáról általánosságban megállapítható, hogy a tranzakciói erősen szabályozottak, és számottevők a föld tulajdonjogának és használati jogának megszerzésére vonatkozó korlátozások. Ezzel a gyakorlattal szemben az EU más tagországaiban (például az Egyesült Királyságban, Görögországban és Luxemburgban) kevésbé szigorúak a birtokszerzésre, a földbérletre és a mezőgazdasági tevékenység folytatására vonatkozó elöírások. A tagállamok birtokpolitikája és sza- 
bályozása tehát messze nem egységes, sőt sokszor országon belül is eltérést mutat (Kelemen [2007]). A visegrádi négyek földpiacának közös vizsgálatát az támasztja alá, hogy földpiaci szabályozásuk számos közös pontot tartalmaz, például a nem rezidens gazdasági szereplők földvásárlása mind a négy országban korlátozás alá esik. A legfőbb szempontokat a 2. táblázat foglalja össze.

2. táblázat

A termőföldvásárlás jogi feltételei a visegrádi országokban, 2015

\begin{tabular}{c|c|c|c}
\hline Ország & $\begin{array}{c}\text { Vásárolhat-e földet a vagyonszerzési korlátozás } \\
\text { ellenére küllöldi természetes személy? }\end{array}$ & $\begin{array}{c}\text { Váśárolhat-e jogi } \\
\text { személy mezögaz- } \\
\text { dasági földet? }\end{array}$ & $\begin{array}{c}\text { Vásárolhat-e földet az országban } \\
\text { bejegyzett, de külföldi tulajdonú } \\
\text { gazdasági társaság? }\end{array}$ \\
\hline Csehország & $\begin{array}{c}\text { Igen (bármilyet), ha három éve állandó } \\
\text { lakhellyel rendelkezik az országban, gaz- } \\
\text { dálkodik, és házastársa cseh állampolgár. }\end{array}$ & Igen & Igen, ha kisebbségi tulajdonos \\
\hline \multirow{5}{*}{ Magyarország } & $\begin{array}{c}\text { Igen, ha az EU valamely tagállamának } \\
\text { állampolgára, minimum három éve legáli- } \\
\text { san tartózkodik az országban, legalább } \\
\text { három éve mezőgazdasági tevékenységet } \\
\text { folytat, és mezőgazdasági termelőként le } \\
\text { kíván telepedni. }\end{array}$ & Nem & Nem \\
\hline \multirow{5}{*}{ Lengyelország } & $\begin{array}{c}\text { Igen (a bérelt területet megvásárolhatja), ha } \\
\text { három éve állandó lakhellyel rendelkezik } \\
\text { az országban, gazdálkodik, és házastársa } \\
\text { lengyel állampolgár. }\end{array}$ & Igen & Igen, ha kisebbségi tulajdonos \\
\hline Szlovákia & $\begin{array}{l}\text { Igen (a bérelt területet megvásárolhatja), ha } \\
\text { három éve állandó lakhellyel rendelkezik } \\
\text { az országban, gazdálkodik, és házastársa } \\
\text { szlovák állampolgár. }\end{array}$ & Igen & Igen \\
\hline
\end{tabular}

Forrás: Saját szerkesztés a mezö- és erdőgazdasági földek forgalmáról szóló 2013. évi CXXII. törvény és Erdélyi [2009] alapján.

A vizsgált négy országban - a 2015. évi állapotok szerint legalábbis - kivétel nélkül korlátozás alá esik a külföldi természetes személyek földtulajdonszerzése. A szabályozással arra törekednek, hogy a természetes személyek közül csak a mezögazdasági tevékenységet folytató „belföldiek” jussanak termőföldhöz. Lengyelország és Szlovákia emellett a külföldiek által megvásárolható földterületeket tovább szükíti azzal, hogy a vásárlás feltételeit kielégítő, nem rezidens személy csak az általa már korábban bérbe vett területet vásárolhatja meg. A korlátozás általában nem vonatkozik a (jellemzően 0,4-1,0 hektárnál) kisebb kiterjedésü földek (például rekreációs célból történő) megszerzésére (bár országonként eltérő a területnagyság). 
Belföldön bejegyzett jogi személyek a termőföld tulajdonjogát Magyarország kivételével az összes visegrádi országban megszerezhetik. Ugyanez vonatkozik azokra a belföldi jogi személyiségủ gazdasági társaságokra is, amelyek kisebbségi tulajdonosa külföldi. Többségi külföldi tulajdonú gazdasági társaságok számára a földvásárlás a visegrádi országcsoporton belül csak Szlovákiában engedélyezett.

A külföldi természetes személyek földvásárlására tehát a visegrádi négyeken belül hasonló korlátozások vannak érvényben. A magyar szabályozás annyiban szigorúbb a csehnél, a lengyelnél vagy a szlováknál, hogy a belföldi jogi személyek tulajdonszerzését is megtiltja, továbbá a belföldi magánszemélyek földvásárlását „földműves" minősítéshez köti, amit a területileg illetékes földhivatal vesz nyilvántartásba. A cím megszerzésének előképzettségi és egyéb feltételei is vannak. A szabályok értelmében tehát a magyar földpiac tekinthető a legkevésbé likvidnek a régión belül (ugyanakkor megjegyezzük, hogy a 2014 elötti földforgalmi szabályok élénkebb forgalmat tettek lehetővé). Lengyelországban és Csehországban a belföldi kereslet által generált földforgalom a magyarországinál nagyobb, azonban minimális a helyi termőföld iránti külföldi érdeklődés. Szlovákiában ugyanakkor a megengedő szabályozásnak köszönhetően szignifikáns a külföldi jelenlét, bár ott is a belföldi eredetü kereslet a meghatározó.

A mezőgazdasági mủvelés alatt álló területeket az EU 27 tagállamában több mint 50 százalékban a tulajdonosok maguk hasznosítják. Ez az arány ugyanakkor nagymértékben változó tagállamonként, illetve birtokméret-kategóriák szerint. A gazdaságok méretének növekedésével ugyanis emelkedik a bérelt terület aránya a saját tulajdonhoz képest. Az EU valamennyi tagállamára igaz, hogy azok a gazdaságok, melyek 50 hektárnál nagyobb területen müködnek, annak nagyobb részét bérlik, míg a kisebbek inkább saját tulajdonban levő földeken gazdálkodnak. A kis területen vagy nagy „léptékben” tevékenykedő farmgazdaságok részesedése az összes mezögazdasági területből tagállamonként eltérő: Lengyelországban az 50 hektár felett, illetve a 100 hektár feletti összterületen gazdálkodók csak az összes földterület kis hányadát $(<20 \%)$ müvelik, Magyarországon a 100 hektár feletti gazdaságok részesedése az összes művelt területből mintegy 40 százalék, míg Csehországban és Szlovákiában egyaránt magas, 90 százalék körüli.

Mivel a birtokkoncentráció - mint azt említettük - nemzetközi tapasztalatok szerint elsődlegesen bérleti jogviszonyon alapuló földhasználat keretei között megy végbe, nagyobb átlagos birtokmérettel azokban az országokban lehet találkozni, ahol fejlettebb a földbérleti piac. Az utóbbi kibontakozását elősegítő legfontosabb tényezőknek a következőket tekinthetjük:

- a bérlő érdekeit védő, nemzeti jogszabályok megléte;

- kis ország- vagy megmüvelhető termőföldterület, amely a földárak magas egyensúlyi szintjéhez vezet; 
- a földtulajdonosok alacsony eladási hajlandósága a magas népsürüségü és kevés termőfölddel rendelkező országokban;

- a szántó mủvelési ág magas aránya (jelentős gabonatermesztés), azaz magas területi igény, amely esetén a földterület növelésének jó alternatívája a bérlet;

- a földalapú befektetések alacsony elvárt hozamszintje miatt a bérleti díjak közösségi szinten is alacsonyak;

- történelmi okok (például Lengyelországban, ahol a családi gazdaságok a szocialista rendszerben is tovább múködhettek vagy Magyarországon, ahol az 1990-es évek eleji kárpótlást követően a tulajdonviszonyok rendkívüli mértékben „szétaprózódtak”) (Erdélyi [2009]).

\section{Piaci árak és árkonvergencia}

A termőföld bérleti díjának és hektáronkénti árának alakulásában mind az új, mind a régi EU-s tagországok esetében növekedést tapasztalhattunk az elmúlt 10-15 évben. Kutatásunk során ezt a folyamatot a visegrádi országok csoportján belül vizsgáljuk részletesen. A földbérleti piac szerepe Nyugat-Európához hasonlóan a 2004ben csatlakozott tagállamokban is jelentős, habár igen változatos képet mutat. Szlovákiában és a Csehországban 90 százalék körüli a bérelt földterületek aránya az öszszes mezőgazdasági művelés alatt álló területen belül, Magyarországon 50-60 százalék közötti, míg Lengyelországban csak 25 százalék. A 100 hektárnál nagyobb gazdaságok által hasznosított és a bérelt területek aránya az összes mezőgazdasági területen belül egymáshoz képest többnyire csak 5-15 százalékpontos eltérést mutat, ami szintén alátámasztja azt a megállapítást, hogy a birtokkoncentráció elsődleges módja a bérleti szerződések útján való terjeszkedés.

A termőföldpiaci árszínvonal visegrádi országcsoporton belüli, hosszú távú változásainak vizsgálatához több adatbázist használtunk fel. Egyes források, mint például az FHB évente frissített kimutatása vagy a prágai székhelyủ Hypotecní Banka által összeállított adatsor láncindexek segítségével követi nyomon a földárak éves változásait. Más források jellemzően az ingatlanforgalomban részt vevő állami hatóságok (föld- és illetékhivatalok) tranzakciós adatbázisából készült kimutatásokra támaszkodnak.

Az országos és a regionális földárakról rendelkezésre álló primer és szekunder forrásokat a 3. táblázat foglalja össze. A különböző adatforrásokból származó adatokat először indexáltuk, hogy a különböző időszakokat lefedő sorozatok összefüzésével országos szinten meghatározhassuk az egyes évek közötti nominális árváltozás mértékét. Ezt követően a 2015. évi árszintet euró/hektár alapon figyelembe véve, 
országonként kiszámítottuk a 2000 és 2014 közötti időszakra az éves átlagos termőföldárakat.

2. ábra. Átlagos árak a visegrádi országok termöföldpiacain, 2000-2015

(euró/hektár)

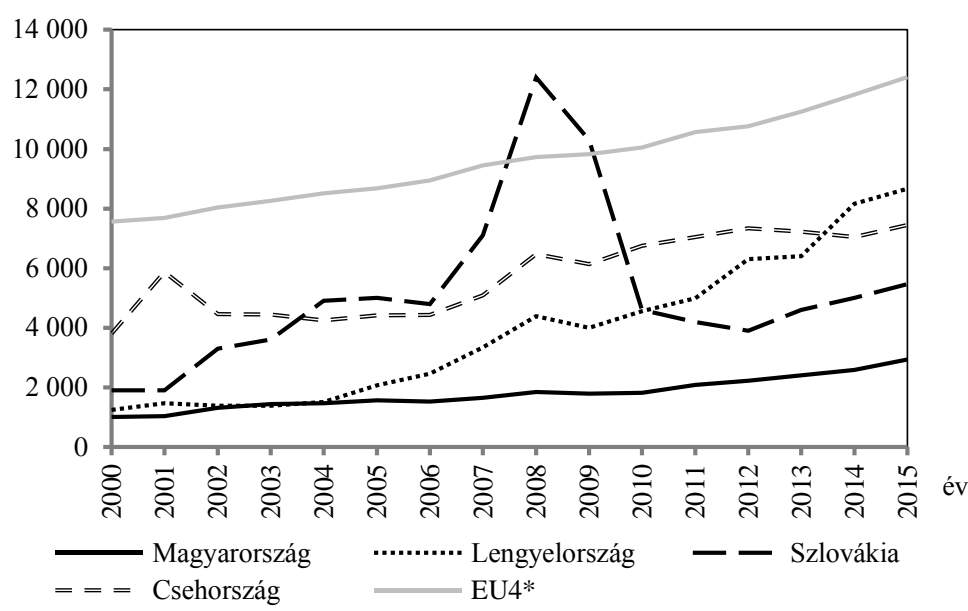

* EU4: Franciaország, Németország, Olaszország és Spanyolország súlyozott átlaga.

Forrás: A 3. táblázatban felsorolt adatbázisok, valamint a Bodenverwertungs- und -verwaltungs GmbH [2016] alapján saját szerkesztés.

3. táblázat

Termöföldárakat közlö források gyüjteménye

\begin{tabular}{|c|c|c|c|}
\hline Adatbázis neve & Adatok típusa & Lefedettség & Forrásmegjelölés \\
\hline \multicolumn{4}{|c|}{ Magyarország } \\
\hline FHB-termőföldindex & nominális éves árváltozás & $\begin{array}{c}\text { országos } \\
2000-2014\end{array}$ & $F H B[2015]$ \\
\hline $\begin{array}{l}\text { Mezőgazdasági termőföld- } \\
\text { árak és bérleti díjak }\end{array}$ & tranzakciós adatbázis & $\begin{array}{l}\text { országos } \\
\text { 2009-2014 }\end{array}$ & $K S H$ [2015] \\
\hline OTP-értéktérkép & tranzakciós adatbázis & $\begin{array}{c}\text { NUTS } 3 \text { (megyék) } \\
\text { 2010-2015 } \\
\end{array}$ & $\begin{array}{c}\text { OTP Jelzálogbank } \\
\text { [2011-2016] }\end{array}$ \\
\hline \multicolumn{4}{|c|}{ Lengyelország } \\
\hline $\begin{array}{l}\text { A lengyel termőföldárak } \\
\text { alakulásának dinamikája }\end{array}$ & egyedi kimutatás & $\begin{array}{c}\text { országos } \\
2004-2015\end{array}$ & Chrzanowska [2016] \\
\hline $\begin{array}{l}\text { Mezőgazdasági és vidéki } \\
\text { területek statisztikai } \\
\text { évkönyve }\end{array}$ & tranzakciós adatbázis & $\begin{array}{l}\text { NUTS } 2 \text { (vajdaságok) } \\
\text { 2000-2014 }\end{array}$ & GUS Poland [2015] \\
\hline
\end{tabular}

(A táblázat folytatása a következö oldalon.) 


\begin{tabular}{|c|c|c|c|}
\hline Adatbázis neve & Adatok típusa & Lefedettség & Forrásmegjelölés \\
\hline \multicolumn{4}{|c|}{ Szlovákia } \\
\hline Átlagos piaci termőföldárak & egyedi kimutatás & $\begin{array}{l}\text { országos } \\
\text { 2001-2013 }\end{array}$ & $\begin{array}{c}\text { Buday-Grausová } \\
\text { [2015] }\end{array}$ \\
\hline $\begin{array}{l}\text { Mezőgazdasági termőföld- } \\
\text { árak Szlovákiában }\end{array}$ & egyedi kimutatás & $\begin{array}{l}\text { országos } \\
2001-2007\end{array}$ & $\begin{array}{c}\text { Takác-Bandlerová } \\
{[2010]}\end{array}$ \\
\hline $\begin{array}{l}\text { Eladó mezőgazdasági } \\
\text { földterületek }\end{array}$ & ingatlanhirdetések & $\begin{array}{c}\text { NUTS } 2 \text { (régiók) } \\
\text { 2014-2016 }\end{array}$ & Biospotrebitel [2016] \\
\hline $\begin{array}{l}\text { Mezőgazdasági termőföld- } \\
\text { árak és bérleti díjak }\end{array}$ & tranzakciós adatbázis & $\begin{array}{c}\text { országos } \\
2000-2009 \\
\end{array}$ & Eurostat [2016] \\
\hline \multicolumn{4}{|c|}{ Csehország } \\
\hline $\begin{array}{l}\text { Csehországi földpiaci } \\
\text { adatok }\end{array}$ & egyedi kimutatás & $\begin{array}{c}\text { országos } \\
\text { 2000-2003 }\end{array}$ & Vrbová-Nemec [2005] \\
\hline $\begin{array}{l}\text { Hypotecní Bank- } \\
\text { területindex }\end{array}$ & nominális éves árváltozás & $\begin{array}{c}\text { országos } \\
\text { 2009-2015 }\end{array}$ & $\begin{array}{c}\text { Hypotecni Banka } \\
\text { [2016] }\end{array}$ \\
\hline $\begin{array}{l}\text { Mezőgazdasági termőföld- } \\
\text { árak és bérleti díjak }\end{array}$ & tranzakciós adatbázis & $\begin{array}{c}\text { országos } \\
\text { 2000-2009 }\end{array}$ & Eurostat [2016] \\
\hline Földterület & ingatlanhirdetések & $\begin{array}{l}\text { NUTS } 2 \text { (régiók) } \\
\text { 2015-2016 }\end{array}$ & mapio.cz [2016] \\
\hline
\end{tabular}

Forrás: Saját szerkesztés.

A 2000-től 2015-ig tartó másfél évtized folyamán a termőföldárak a visegrádi országokban (évi 4,6-13,8 százalékkal) markánsabban emelkedtek, mint a régi tagállamokban (amelyekben átlagosan évi 3,4 százalékkal). Ezzel párhuzamosan a négy ország termőföld-árszínvonala közötti relatív szórás 15 év alatt a 60-80 százalékos szintről 40 százalékra, a legalacsonyabb és a legmagasabb országos árszint közötti eltérés pedig négyszeresről háromszorosra csökkent. A leggyorsabb emelkedés Lengyelországban volt megfigyelhető, ahol egy hektár mezőgazdasági földterület átlagos vételára a 2000. évi 1250 euróról 2008-ra 4400 euróra nőtt, majd a 2008/2009-es pénzügyi és gazdasági világválságot követő években tovább növekedve, 2015-re kevéssel meghaladta a 8600 euró/hektárt. (Lásd a 2. ábrát.) A lengyel termőföldárszínvonal ezzel 2014-től, átlépve a csehet, a visegrádi országcsoporton belül a legmagasabb lett. A nemzetközi összehasonlításban is kiugró áremelkedésre három, egymást kölcsönösen erősítő folyamat szolgált magyarázatul: 1 . a lengyel mezőgazdaság hektáronkénti termelékenysége a tizenöt éves periódusban töretlenül növekedett; 2. történelmi okok miatt a lengyel bérleti piac alulfejlettsége élénkítette a termőföldek iránti vevői keresletet, mivel gyakran a vétel jelentette a birtokfejlesztés 
egyetlen lehetséges módját; 3. az EU régi tagállamainak körében élénknek nevezhető német földpiac közelsége miatt a cseh, a szlovák és a magyar viszonyoknál jobban érvényesülhetett az európai uniós csatlakozást követö árkonvergencia.

Lengyelországban - mint már említettük - történelmi okok miatt mind az európai uniós átlaghoz, mind a többi visegrádi országhoz viszonyítva alacsonyabb a bérelt területek aránya; jóllehet az átlagérték országon belüli változatosságot takar. A mutató ugyanis az ország déli részén a 10 százalékot sem éri el, míg északon ennél lényegesen magasabb. A régión belül lengyel sajátosság, hogy a családi tulajdonú gazdaságok a szocialista időkben is müködhettek, a lengyel mezőgazdaság fejlődését így - ellentétben a magyar, a cseh és a szlovák agráriuméval - nem törte meg az 1950-es és az 1960-as években véghezvitt kollektivizálás, majd az 1990-es években kibontakozó reprivatizáció. Egyedül az ország nyugati és északnyugati régióiban volt jelentős az összes gazdaságon belül az államiak aránya, ebből adódóan ezekben az országrészekben ma is 40-50 százalék a 100 hektár feletti birtokkal rendelkező gazdaságok részesedése az összes művelhető területből. A déli és a keleti országrészben föként kis- és közepes méretü családi gazdaságok müködnek, ezért a bérelt területek aránya is alacsony. Lengyelországban a rendszerváltást követően csak a nyugati és az északnyugati területeken koncentrálódó állami gazdaságok, valamint az Állami Földalap használatában levő földeket privatizálták, így az az ország jelentős részén nem volt olyan mértékü átrendeződés, mint Magyarországon, Csehországban vagy Szlovákiában (Erdélyi [2009]).

A visegrádi országok közül - mint azt az 1. táblázat is mutatja - Lengyelország rendelkezik a legtöbb mezőgazdasági földterülettel. Az 1995 és 2005 között zajlott földprivatizáció során több mint 100 ezer egyedi tranzakció keretében értékesítették az állami földvagyon döntő részét. Ugyanakkor a magántulajdonú földek iránti érdeklődés mértékét mutatja, hogy ebben az időszakban több mint 1,7 millió hektárnyi olyan föld is gazdát cserélt, ahol az állam nem jelent meg eladó vagy vevő félként. A termőföldvagyon éves forgási sebessége az összes lengyelországi müvelhető terület 1,0 és 2,5 százaléka között mozgott a 2008-as válság előtti időszakban (TakácBandlerová [2010]).

Csehországban a földárak a 2000-2007-es időszakban stabilitást mutattak, az átlagos hektáronkénti vételár kisebb ingadozásokkal a 4 000-6 000 eurós tartományban mozgott. Jelentős áremelkedés a 2008 és 2012 közötti öt évben zajlott le. 2012ben 7340 euró/hektár, 2015-ben 7450 euró/hektár volt az átlagos értékesítési ár. Csehországban a kollektivizálás során kisajátított földtulajdont a lehető legteljesebb körben visszaadták. A mezőgazdasági szövetkezetek az 1992-es átalakulási törvény értelmében a vagyon nevesítésével indították a privatizációt, átalakulásuk 1993 januárjára fejeződött be. A vagyonjegyek 50 százalékát a szövetkezet létrehozásakor kisajátított föld, 30 százalékát a kisajátításra került egyéb vagyontárgyak, 20 százalékát pedig a szövetkezeteknél végzett munka arányában osztották szét a tagok között. A szövetkezeteknél dolgozók 80 százaléka azonban nem rendelkezett kollektivizált 
vagyonnal és földdel, ezért a nevesített vagyon nagy része „kívülállókhoz” került. Jelenleg az átalakult, piacgazdasági alapokra helyezett szövetkezetek adják a cseh mezőgazdasági termelés domináns részét, hiszen az aktív gazdálkodók (egyéni gazdaságok és gazdasági szervezetek) együttes száma csupán néhány tízezerre tehető.

A mezőgazdasági termelésben közvetlenül részt vevő vállalkozások átalakításának ütemezéséhez hasonlóan, 1993-ra 95-96 százalékban privatizálták a csehországi élelmiszeripart is a kuponos privatizáció módszerével (Erdélyi [2009]).

Az 1990-es évek eleje és a 2000-es évek vége között a cseh földforgalom dinamikus növekedést mutatott, az 1995 elötti évekre jellemző 0,3 százalék körüli éves forgási sebesség a 2002-2004 években 1,5 százalékra, majd a 2000-es évek végére már évi 3 százalék fölé emelkedett. Az összességében több mint tízszeres földforgalom-emelkedést Csehország transzformációs recesszióból való kilábalása, a területalapú támogatási rendszer európai uniós csatlakozást követő bevezetése és az egyre alacsonyabb kamattal igényelhető, hitelgaranciával kombinált földvásárlási kölcsönök elterjedése segítette elö (Takác-Bandlerová [2010]).

Szlovákiában a cseh mintához hasonlóan az 1992. évi föld- és átalakulási törvények rendelkeztek az agrárprivatizációról, amelynek célja az eredeti földtulajdon visszaállítása és az ingó mezőgazdasági vagyon tulajdonviszonyainak regisztrálása volt. Az első privatizálási hullám több állami tulajdonú gazdaságot, mintagazdaságot, mezőgazdasági szolgáltató és integrátor vállalatot érintett, és az eredetinél kisebb gazdasági egységek kialakításával kezdődött (Erdélyi [2009]). A szövetkezetek száma így 630-ról 968-ra növekedett, az átlagos üzemméret viszont számottevően csökkent (2005-re 143 hektárra), ami a Magyarországiéhoz és a Lengyelországiéhoz képest még így is magasabb volt (Strelecek-Lososova-Zdenek [2009]). A szövetkezetek által használt vagyon 41 százaléka jelenleg külső tulajdonosok birtokában van, és ez számos konfliktus forrása. A mezőgazdasági földek forgási sebessége Szlovákiában (volt) a legalacsonyabb a régión belül, a 2000-es években az adásvétel útján gazdát cserélt területek éves aránya az összes müvelhető földterület 1,0 százalékát sem érte el (Takác-Bandlerová [2010]).

Szlovákia földpiaca 2000 és 2004 között, az európai uniós csatlakozást megelözö időszakban forgalmi szempontból mérsékelt élénkülést mutatott, ugyanebben az időszakban egy hektár föld ára 1900 euróról közel 5000 euróra nőtt. Az árak 2004-2006-es időszakban stagnáltak, majd a válság előtti utolsó években, többek között a visegrádi országokra ekkor jellemző erőteljes külső forrásbevonás és devizaalapú hitelezési hullám hatására a termőföldpiacon is árbuborék alakult ki az épített ingatlanokéhoz hasonlóan. 2008-ban 12400 euró, 2009-ben 10300 euró volt az átlagos hektárár. A folyó fizetési mérleg korrekciójára a válság alatt került sor, ami a külső források elapadásával együtt kifejtette a hatását a földpiacon: az átlagos árszint 2012-ig 4000 euró/hektár közelébe zuhant, majd a szlovák gazdaság kilábalásának megindulásával ismét emelkedni kezdett. Így 2015-ben már 
5470 euró/hektár átlagáron cseréltek gazdát a szlovákiai termőföldek. Az árbuborék kialakulásában - és abban, hogy ez a folyamat egyedül Szlovákiában jelentkezett ennyire markánsan - a szlovák földforgalmi szabályok külső befektetők számára kedvező rendelkezései játszhattak szerepet. Szlovákiában - ugyanis mint azt már bemutattuk - nincs korlátozva a gazdasági társaságok és ezeken belül a kisebbségi vagy többségi külföldi tulajdonú vállalkozások termőföldvásárlása. A hitelezés 2008-as válság előtti hirtelen felfutása és a pozitív árvárakozások, a mezőgazdasági termelők körén kívül eső érdeklődők figyelmét is a földalapú befektetések felé fordíthatták, a növekvő keresleti nyomás pedig egészen a finanszírozás 2009-re tehető elapadásáig felfelé hajtotta a piaci árakat.

4. táblázat

A termöföld-alapterület és a kinálati ár közötti összefüggések a szlovákiai termöföldpiacon, 2016

\begin{tabular}{|c|c|c|c|c|c|c|c|}
\hline \multirow[b]{2}{*}{ Megnevezés } & \multirow{2}{*}{$\begin{array}{c}\text { Összes } \\
\text { termőföld }\end{array}$} & \multicolumn{6}{|c|}{ Termőföld-alapterület } \\
\hline & & $<1$ hektár & 1-5 hektár & 5-10 hektár & 10-20 hektár & $\begin{array}{l}20-50 \\
\text { hektár }\end{array}$ & > 50 hektár \\
\hline $\begin{array}{l}\text { Átlagos ár } \\
\text { (euró/hektár) }\end{array}$ & 6079 & 3695 & 6042 & 9022 & 6165 & 3995 & 4529 \\
\hline $\begin{array}{l}\text { Medián ár } \\
\text { (euró/hektár) }\end{array}$ & 4100 & 3500 & 4100 & 7000 & 4500 & 3900 & 3650 \\
\hline $\begin{array}{l}\text { Tapasztalati szórás } \\
\text { (euró/hektár) }\end{array}$ & 5653,1 & 2339,1 & 6154,1 & 7737,6 & 4245,0 & 1213,5 & 2161,6 \\
\hline $\begin{array}{r}95 \text { százalékos konfi- } \\
\text { dencia-intervallum }\end{array}$ & & & & & & & \\
\hline alsó (euró/hektár) & 5094 & 2282 & 4346 & 5676 & 4178 & 3127 & 2983 \\
\hline felsö (euró/hektár) & 7064 & 5108 & 7738 & 12368 & 8152 & 4863 & 6075 \\
\hline Megfigyelések száma & 129 & 13 & 53 & 23 & 20 & 10 & 10 \\
\hline $\begin{array}{l}\text { Fơátlagtól számított } \\
\text { eltérés iránya }\end{array}$ & & - & & + & & - & - \\
\hline Szignifikancia & & $*$ & $\mid \begin{array}{c}\text { nem } \\
\text { szignifikáns }\end{array}$ & * & $\begin{array}{c}\text { nem } \\
\text { szignifikáns }\end{array}$ & $* * *$ & ** \\
\hline
\end{tabular}

Megjegyzés. $* p=0,1$ szinten, $* * p=0,05$ szinten, *** $p=0,01$ szinten szignifikáns. Az egymásba kapcsolódó nagyságkategóriák oka, hogy a termőföld-alapterület ebben a bontásban folytonos változónak tekinthető.

Forrás: A Biospotrebitel [2016] ingatlanhirdetései alapján saját számítás.

Szlovákiában a Biospotrebitel [2016] online felületen 2015-ben és 2016-ban elhelyezett ingatlanhirdetések alapján, statisztikailag szignifikáns eltérések fedezhetők fel a termőföldterületek méretkategóriái között a hektáronkénti átlagár tekintetében. A mintába 129 darab hirdetés került, melyek Szlovákia teljes területét lefedik. Ezeken 
belül legnagyobb súllyal a nyugat-szlovákiai régió szerepelt, ennek sík területein található a legtöbb mezőgazdasági terület. Míg a 2015. július elejétől 2016. december végéig tartó másfél év átlagos kínálati ára országos szinten 6079 euró volt hektáronként, az egy hektárnál kisebb területek esetében pedig 3695 euró/hektár, a 20 hektárnál nagyobb egybefüggő területek csoportját 4 000-4 500 euró/hektáros átlagárak jellemezték.

Az átlagárakat vizsgálva, az egy hektárnál kisebb földterületek körében 10 százalékos, a 20-50 hektáros eladó termőföldek esetében 1 százalékos, az 50 hektárnál nagyobbaknál pedig 5 százalékos standard szignifikanciaszinten mutatható ki eltérés. Érdekesség, hogy az 5 és 10 hektár közötti táblák fajlagos ára 10 százalékos szignifikanciaszinten számottevően nagyobb a teljes sokaságot jellemző számtani középértéknél. Piaci tapasztalatok szerint a legmagasabb árat a 3 és 20 hektár közötti tartományban kérhetik az eladók. Az ennél kisebb, gyakran egy hektárnál is alacsonyabb kiterjedésủ föld gazdaságos, gépesített hasznosítása nehezen megoldható, amely az árak alakulására is hatással van. A nagyobb, 20 hektár feletti területek esetében pedig a nagyobb forgalmi értékkel összefüggő, alacsony likviditás magyarázza a mérsékelt kínálati árat. A hirdetésekben szereplő áraknak mind a korrigált tapasztalati, mind a relatív szórása a kisebb és közepes méretkategóriáknál magasabb, míg a 20 hektár feletti földterületeknél lényegesen alacsonyabb a teljes sokaságra jellemző értéknél.

3. ábra. Eladó termöföldek kínálati ára alapterület szerint, illetve árszintjük standardizált gyakorisága Szlovákiában, 2015-2016

$$
(N=129)
$$
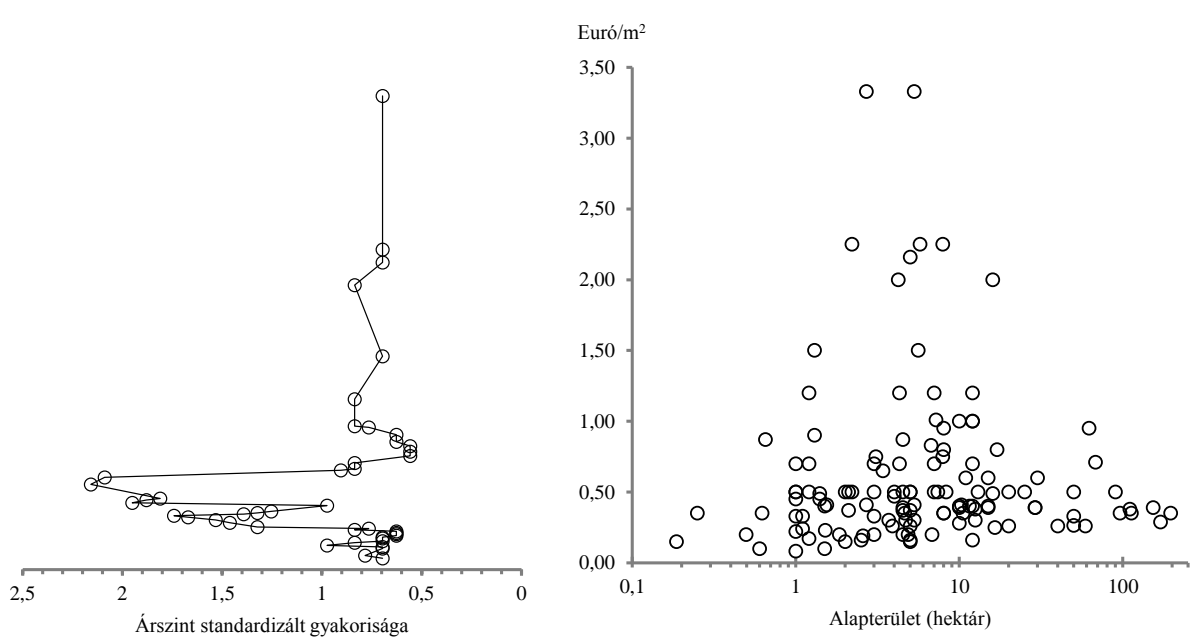

Forrás: A Biospotrebitel [2016] ingatlanhirdetései alapján saját szerkesztés. 
Az összes feldolgozott szlovákiai ingatlanhirdetést áttekintő 3. ábrán látható, hogy a közepes alapterületü, 3-20 hektáros termőföldek ára 2015-ben és 2016-ban meghaladta a kisebb, illetve nagyobb parcellákra jellemző szintet, ugyanakkor a minta szórása is ebben az alcsoportban volt a legmagasabb. A legtöbb eladó mezögazdasági terület kínálati ára négyzetméterenként 47 és 65 eurócent, azaz 4700 és 6500 euró/hektár között mozgott. A minta módusza - ahol a standardizált gyakoriság eléri maximumát -6000 euró/hektár.

Magyarországon jelenleg a teljes termőföldvagyon mintegy 85 százaléka magánkézben van a tulajdonszerkezet rendszerváltozást követő átalakulása nyomán. Ezen belül a szántó, a gyep/legelö és a gyümölcsös müvelési ágak hármasa által alkotott mezögazdasági területen 90 százaléknál is nagyobb a belföldi magánszemélyek tulajdoni aránya. Ennek alapvető oka - mint azt már említettük - a jogi szabályozás, hiszen a termőföldről szóló 1994. évi LV. törvény hatályba lépése óta Magyarországon belföldi magánszemély személyenként 300 hektár vagy 6000 aranykorona mennyiségig, a jogi személyek közül pedig csak az állam, a helyi önkormányzatok és az egyházi jogi személyek szerezhetnek termőföldtulajdont. Azok a jogi személyiségü gazdasági társaságok viszont, amelyek termőföldet még 1994. július 27-e, azaz a jelenlegi földtörvény hatályba lépése előtt szereztek, azt továbbra is tulajdonukban tarthatják (Magda-Szücs [2002] 57-64. old.). Lényegében az ezek által tulajdonolt néhány százezer hektárnyi föld az, ami érdemben képes fejlesztési célú tőkét jelzálogalapú finanszírozás útján befogadni. A magánszemélyek tulajdonában levő földterületek 1/1 tulajdoni hányad esetében általában kisebb kiterjedésü táblák. A nagyobb külterületi táblák nem ritkán 10-nél is több tulajdonos osztatlan közös tulajdonát képezik, és gyakoriak a földdel való rendelkezést tovább korlátozó haszonélvezeti jogok is.

Magyarországon a földforgalom - a többi visegrádi országhoz hasonlóan - az 1990-es évektől kezdve folyamatosan nőtt, a csehországi szinthez állt a legközelebb. Az európai uniós csatlakozást követő 2004-2006 években az éves forgási sebesség már megközelítette a 3 százalékot (Takác-Bandlerová [2010]). A 2008-2009. évi gazdasági válság a földárak töretlen emelkedését Magyarországon nem vetette viszsza, 2008 és 2010 között az Illetékhivataltól átvett és az OTP Bank által kiértékelt, illetve közzétett tranzakciós adatok alapján a mezőgazdasági területek értéke az inflációnál lényegesen nagyobb mértékben, nominálisan 13 százalékkal emelkedett két év leforgása alatt (OTP Jelzálogbank [2011]). Mindezek ellenére elmondható, hogy a régión belül jelenleg Magyarországon találkozhatunk a legalacsonyabb árfekvésü termőföldekkel, amely, figyelembe véve a müvelhető területeknek az ország összterületéhez viszonyított magas arányát, a szántóföldi müvelésre alkalmas, sík területek túlsúlyát, a talajok minőségét és a jó klimatikus adottságokat (a magasabb évi középhőmérsékletet, a hosszú tenyészidőt a haszonnövények számára) az északabbra fekvő országokhoz képest, kedvezőbb feltételeket teremt a magyar gazdák közül azoknak, 
akik birtokfejlesztésre törekednek. 2000 és 2008 között a magyarországi földpiacon az átlagos hektárár 1010 euróról 1848 euróra emelkedett, ami nominális értelemben évi 7,8 százalékos hozamnak felel meg. Utóbbi lényegesen meghaladta a KSH által közzétett inflációs mutatók szintjét, ami a fogyasztói árindexsor alapján 6,0 százalék, a GDP-deflátor szerint pedig 5,9 százalék volt évente. 2008 és 2010 között, a válság éveiben az árak stagnáltak, a cseh, lengyel vagy szlovák földpiacon bekövetkezett csökkenéshez hasonló folyamat azonban nem volt észlelhető. 2011 után gyors növekedés kezdődött, melynek oka részben az volt, hogy rövidesen, 2014-ben lejárt a külföldi magánszemélyek földvásárlására vonatkozó, jogszabályban rögzített moratórium. Az áremelkedés üteme elérte a 10 százalékot is évente. A 2014-ben hatályba lépett új földforgalmi törvény a földvásárlásra jogosultak körét erősen leszükítette, de az áremelkedésnek újabb löketett adott a Nemzeti Földalapkezelő birtokában levő állami földek 2015-ben meghirdetett privatizációja. Így 2014-ben 2590 euró/hektár, 2015-ben pedig 2934 euró/hektár volt az átlagos magyar termőföldár. A 2016. évi piaci információk már az áremelkedés mérséklődésének irányába mutattak: a közzétett gyorsjelentések szerint a forgási sebesség csökkenésével párhuzamosan az árak növekedése is megállt (OTP Jelzálogbank [2016], FHB [2015]).

Az alacsony árszínvonal régiós összehasonlításban a magyar mezőgazdaság alacsony termelékenységéhez, gyenge növekedési kilátásaihoz és általános alultőkésítettségéhez kapcsolható, ugyanakkor a földpiac ármozgásaira kétségtelenül hatással van a visegrádi térségben legszigorúbb jogi szabályozás is. A mezőgazdasági tevékenység finanszírozásában fontos szerepet játszó pénzintézetek termőföldtulajdonjogot tartós befektetési céllal nem szerezhetnek, a bankok közül kizárólag a jelzálog-hitelintézetek tehetnek szert átmeneti jelleggel - hitel-ingatlan csereügylet, illetve adós ellen indított végrehajtás útján - termőföld-tulajdonjogra, majd három éven belül az így szerzett ingatlanaikat nyilvános árverésen kell értékesíteniük (Herbst-Orlovits [2005]). A földek tulajdonjogának megszerzését a mezö- és erdögazdasági földek forgalmáról szóló 2013. évi CXXII. törvény szabályozza. Ez határozza meg a földhasználati jog bérleti vagy más jogcímen való megszerzésének feltételeit is. Termőföld tulajdonjogát Magyarországon nem szerezheti meg EU-n kívüli állampolgárságú külföldi természetes személy, a magyar államon kívül más állam, illetve annak tartománya, helyhatósága vagy azok bármely szerve, valamint a törvényben meghatározott esetek kivételével jogi személy. Mint azt már említettük, belföldiek közül is csak a mezőgazdasági tevékenységet folytató, szakirányú végzettséggel rendelkező ún. „földművesnek” minősülő magánszemélyek szerezhetnek termőföld-tulajdonjogot személyenként 300 hektárig, míg a földhasználati szerződésekkel együtt meghatározott birtokmaximum 1200 hektár. Ennél nagyobb kiterjedésü földterületet csak az állattartó telepek üzemeltetői és a vetőmagot előállító mezögazdasági vállalkozók tarthatnak müvelésükben, esetükben kedvezményes, 1800 hektáros birtokmaximum vehetö figyelembe. 
A termöföldalapú befektetések hozama a visegrádi országokban és Németországban, 2000-2015

\begin{tabular}{|c|c|c|c|c|c|c|c|}
\hline \multirow{3}{*}{ Ország } & \multirow{2}{*}{\multicolumn{2}{|c|}{$\begin{array}{c}\text { Termőföldek átlagára } \\
\text { (euró/hektár) }\end{array}$}} & \multicolumn{4}{|c|}{ Termőföldek befektetési hozamai } & \multirow{3}{*}{$\begin{array}{l}\text { Termöföldek éves } \\
\text { forgási sebessége } \\
\text { az összterület } \\
\text { százalékában }\end{array}$} \\
\hline & & & Átlagos & Első & Harmadik & S7órás & \\
\hline & 2000 & 2015 & \multicolumn{4}{|c|}{$(\%)$} & \\
\hline Lengyelország & 1250 & 8661 & 13,77 & 3,82 & 26,96 & 14,84 & 1,5 \\
\hline Csehország & 3807 & 7456 & 4,58 & $-2,04$ & 7,94 & 17,36 & 3,0 \\
\hline Szlovákia & 1900 & 5472 & 7,31 & $-5,57$ & 27,03 & 34,15 & 1,0 \\
\hline Magyarország & 1010 & 2934 & 7,37 & 2,55 & 10,82 & 7,31 & 2,5 \\
\hline Kelet-Németország & 3631 & 14005 & 9,74 & 2,64 & 18,02 & 8,80 & 1,2 \\
\hline Nyugat-Németország & 16830 & 29706 & 3,98 & $-0,29$ & 6,68 & 5,22 & 0,5 \\
\hline
\end{tabular}

Megjegyzés. Németország nyugati és keleti tartományait a történelmi örökségként is értelmezhető eltérésekre való tekintettel külön átlagoltuk.

Forrás: A 3. táblázatban felsorolt adatbázisok, valamint a Bodenverwertungs- und -verwaltungs GmbH [2016] alapján saját számítás.

Hozamok tekintetében a 2000 és 2015 közötti időszakban a visegrádi országok mindegyikében megfigyelhető volt a földárak konvergálása a nyugat-európai szinthez. Az EU régi tagállamainak többségében a termőföldvagyon forgási sebessége lényegesen elmarad(t) a kelet-európai tagállamokban tapasztalhatótól, ennek egyik oka, hogy a nyugati földtulajdonosok nem szívesen jelennek meg a piacon eladóként, mivel a termőföldre tartós befektetésként tekintenek. Németország nyugati tartományaiban az elmúlt évtizedben 0,5 százalék körül mozgott az adásvétel útján évente gazdát cserélt mezőgazdasági területek aránya az összes müvelt területhez képest. A nyugatnémet tartományok (Bajorország, Baden-Württenberg, Hessen, RajnavidékPfalz, Saar-vidék, Észak-Rajna-Vesztfália, Alsó-Szászország, valamint SchleswigHolstein) földpiacán tapasztalt, éves átlagban 3,98 százalékos nominális áremelkedés az EU régi tagállamainak többségében megfigyelhető változáshoz hasonló nagyságrendủ. Az éves árváltozások alsó kvartilise ugyanitt $-0,29$, felső kvartilise pedig 6,68 százalék volt, melyek alapján a termőföldterületek forgalmi értékének emelkedése az évek többségében meghaladta az euró inflációját. A visegrádi országok mindegyikében ennél nagyobb értéknövekedés következett be, 1,0-3,0 százalékos piaci forgási sebesség mellett.

A leginkább markánsan Lengyelországban emelkedett a termőföld ára évente átlagosan 13,8 százalékkal, mely a vizsgált időszak éveinek felében 4 és 27 százalék között ingadozott. (Lásd az 5. táblázatot.) A lengyel árkonvergenciánál kisebb inten- 
zitású, de ugyancsak jelentős emelkedés volt megfigyelhető Szlovákiában és Magyarországon is, ahol évi 7,3-7,4 százalékkal nőttek a földárak. Az azonos mértékü áremelkedés a korábban ismertetett okokból Szlovákiában nagyobb, Magyarországon kisebb volatilitással párosult. Csehországban a földárak 2000 körül lényegesen magasabb szinten mozogtak a lengyel, a szlovák vagy a magyar piacra jellemzönél, így ebben az országban volt megfigyelhető a legkisebb mértékű drágulás: a mezőgazdasági területek hektáronkénti ára csak 4,6 százalékkal emelkedett évente, azonban még ez is meghaladta a nyugatnémet tartományokban megfigyelt árváltozás mértékét. Ebből adódóan, 2015-ben egy hektár csehországi termőföld átlagára már elmaradt a lengyelországi szinttől, de még mindig jóval meghaladta a szlovák vagy a magyar árszínvonalat. A volt keletnémet területeken - Türingia, Szászország, SzászAlhalt, Brandenburg, valamint Mecklenburg Elö-Pomeránia tartományokban - 2000 és 2015 között intenzíven, évente közel 10 százalékkal emelkedtek a földárak, ami a szomszédos lengyel piacon észlelt tendenciához áll a legközelebb.

6. táblázat

A visegrádi országok és a keletnémet tartományok

földpiaci árváltozásai közötti korrelációs együtthatók, 2000-2015

\begin{tabular}{l|c|c|c|c}
\hline \multicolumn{1}{c|}{ Ország } & Lengyelország & Csehország & Szlovákia & Magyarország \\
\hline Lengyelország & - & & & \\
\hline Csehország & $\mathbf{0 , 4 4 9}$ & - & & \\
& $(\mathbf{0 , 0 9 2 7 )}$ & & & \\
\hline Szlovákia & 0,085 & $-0,095$ & & \\
& $(0,7624)$ & $(0,7354)$ & - & \\
\hline Magyarország & $-0,146$ & $-0,290$ & $\mathbf{0 , 6 0 7}$ & \\
& $(0,6041)$ & $(0,2943)$ & $(\mathbf{0 , 0 1 6 3})$ & - \\
\hline Keletnémet tartományok & $-0,080$ & 0,076 & $-0,289$ & $-0,025$ \\
& $(0,7757)$ & $(0,7890)$ & $(0,2945)$ & $(0,9307)$ \\
\hline
\end{tabular}

Megjegyzés. Zárójelben az összefüggések hiányának bekövetkezési valószínűségét mérő $p$-értékek olvashatók. A vastagított adatok szignifikáns kapcsolatra utalnak.

Forrás: A 3. táblázatban felsorolt adatbázisok, valamint a Bodenverwertungs- und -verwaltungs GmbH [2016] alapján saját számítás.

Amennyiben az éves árváltozást mérő százalékos mutatók közötti keresztkorrelációs kapcsolatokat a visegrádi országok, illetve a volt keletnémet tartományok körében vizsgáljuk, a 2000 és 2015 közötti időszakban két szignifikáns együttmozgást fedezhetünk fel. A korrelációs együttható a lengyelországi és a csehországi éves árváltozások között pozitív, 0,449; a kapcsolódó nullhipotézis, azaz az összefüggés hiányának bekövetkezési valószínúségét mérő $p$-érték 0,0927 , mely 10 százalékos 
szignifikanciaszinten kizárja a függetlenséget. Ugyancsak kapcsolat fedezhető fel a szlovák és a magyar piac között is, ennek korrelációs együtthatója még a lengyel és cseh közöttinél is magasabb $(0,607)$, továbbá az összefüggés 5 százalékos szignifikanciaszinten is vélelmezhető. A többi relációban nem mutatható ki statisztikailag igazolható együttmozgás. Csehország és Szlovákia piaci tendenciái között pedig annak ellenére sincs összefüggés, hogy a két ország - a közös múlt következtében - megközelítőleg azonos birtokszerkezettel rendelkezik, és mezőgazdasági termelésükben meghatározó szerepet töltenek be a 100 hektár feletti területen gazdálkodó vállalkozások. Mủvelési ágak terén Magyarország és Szlovákia annyiban hasonlít egymásra, hogy mindkét országban kiemelkedő a szántóföldi gazdálkodás szerepe, míg a legelők és az állattartó üzemek részesedése kisebb jelentőséggel bír. Utóbbi szöges ellentétben áll a lengyel és a cseh mezőgazdaság termelési szerkezet, ahol a szántóföldi növénytermesztés és az állattartás szerepe kiegyenlítettebb, továbbá Lengyelországban fejlett még a kertészeti ágazat is.

Az új tagállamokban a földárak konvergenciáján felül 2004 után a mezőgazdasági termelöi és inputárak is közeledtek a régi tagállamokban megfigyelt árszínvonalhoz. A mezőgazdasági szektorban az európai uniós csatlakozással azonnal kibontakozott, és kevesebb mint fél évtized múltán, a 2008-2009-es recesszió idejére már megvalósult általános árkonvergencia a termőföldpiacon némileg késve jelentkezett, ami alátámasztja a földpiac lassú reakcióját a gazdasági környezet változásaira. Megállapítható az is, hogy a földárak mozgása az agrárszektor termelékenységét mérő, egy hektárra jutó STÉ (standard termelési érték) mutató alakulásával - Lengyelország kivételével - nem volt összefüggésben (Csaki-Jambor [2013], Eurostat [2016]). Az országonkénti árváltozás mértéke számottevő kapcsolatot mutatott ugyanakkor az egy före jutó GDP-növekedés ötéves átlagaival: a reál-GDP Eurostat által közzétett növekedési adatai az éves termőföldár-változások országok közötti és időbeli eltéréseit közel 50 százalékban magyarázták.

Takác-Bandlerová [2010] megállapították, hogy a mezőgazdasági földterületek árának emelkedése a visegrádi országokban csak 2-3 évvel a csatlakozás után, 2007 körül gyorsult fel, ezzel szemben a termelöi értékesítési és inputáraké szinte azonnal. Az áremelkedések következtében 2004-ben és 2005-ben 20-75 százalékkal növekedett a mezőgazdasági vállalkozások egységnyi munkaerö-felhasználásra jutó reáljövedelme. Legnagyobb mértékủ változás a csatlakozás utáni első két évben Lengyelországban és Csehországban, a legkisebb pedig Szlovákiában volt tapasztalható. Magyarország esetében az egy munkaerőegységre jutó reáljövedelem-emelkedés 50 százalékot tett ki (Csaki-Jambor [2013]). Az, hogy a termelöi árak mellett az inputárak (a munkaerő, a vetőmagok, a mütrágyák, az üzemanyagok és a növényvédőszerek árának) növekedése is gyorsan jelentkezett, a mezőgazdasági termelőket az inputok hatékonyabb alkalmazására ösztönözte, ami például az egységnyi felhasznált munkaeröre jutó reáljövedelem emelkedésében öltött testet. A 
mezőgazdasági inputárak emelkedése - Lengyelország kivételével - a visegrádi országokban 2006 után lassult le. Míg a kezdeti növekedés hátterében elsősorban az anyagi és a személyi jellegü inputok áremelkedése állt, a későbbiében a termőföldpiacon tapasztalható keresletélénkülés.

A piaci folyamatokon túl a bérleti díjak és a földárak növekedésének lehetséges okai közé egyrészt a termesztési technológiákban bekövetkezett átalakulások, másrészt az Európai Unió által nyújtott földalapú támogatások teljes összegủ kifizetéseinek szigorodó feltételei sorolhatók. Ezek a korábbinál extenzívebb gazdálkodási gyakorlatot (például 2015-tôl ökológiai célterület kijelöléséhez kötött a földalapú támogatási keret teljes lehívása a nagyobb területen gazdálkodók esetében), valamint új technológiai elemek (öntözés, belvízvédelem stb.) kiépítését, azaz értéknövelö beruházásokat tesznek szükségessé. További kérdést vet fel, hogy egyes növények (repce, napraforgó, energiafú, energianád) energiagazdálkodásban kikényszerített szerepe milyen mértékben képes növelni európai uniós szinten a termőföld iránti keresletet, és - tekintettel a földterületek rugalmatlan kínálatára - az élelmezési célú hasznosítás közvetlen alternatívájaként milyen mértékben emeli majd a termőföld átlagos hektáronkénti értékét (Erdélyi [2009]).

\section{Országokon belüli, regionális árkülönbségek}

A visegrádi térség földpiacát jellemző általános árkonvergencia mellett regionális szinten továbbra is számottevő eltérések mutatkoznak a termőföld értékének alakulásában. Kutatásunk során arra az eredményre jutottunk, hogy az egyes térségek közötti árszínvonal-különbségek sokkal inkább a gazdasági-társadalmi fejlettség eltérő szintjével magyarázhatók, mint a vizsgált régiók természeti-ökológiai adottságainak - például talajtípusainak, domborzatának, klimatikus viszonyainak különbségeivel.

Egy hektár termőföld ára a visegrádi országok körében Magyarországon a legalacsonyabb (ezen belül is az ország kevésbé fejlett, keleti-északkeleti régióiban) annak ellenére, hogy az ország löszös területein kialakult mezőségi talajok és barna erdőtalajok termékenysége kitűnőnek mondható, és emellett a vegetációs időszak hossza, illetve a nyári félév höösszege is hazánkban a legkedvezőbb. A földforgalom jogi szabályozásában felmerülő különbségek önmagukban nem magyarázzák az országok, illetve régiók közötti különbségeket: Szlovákiában, ahol a földforgalmi szabályok a leginkább megengedők, a visegrádi régión belül a második legalacsonyabb árszint alakult ki, míg a szigorúnak mondható lengyelországi földpiaci szabályozás ellenére a lengyel termőföldek ára a legmagasabb a térségben. 
4. ábra. A termőföldár és magyarázó tényezöinek regionális eltérései a visegrádi országokban

a) Termöföldek piaci átlagára, 2015 (euró/hektár)

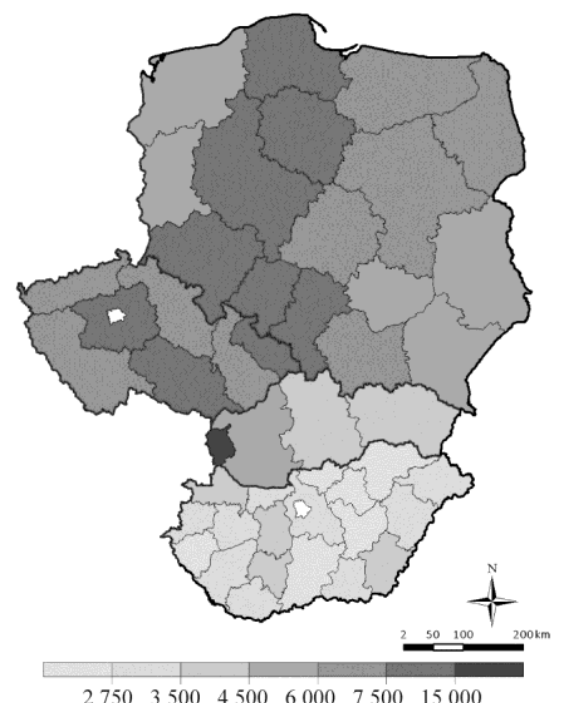

c) Átlagos birtokméret, 2013 (hektár)

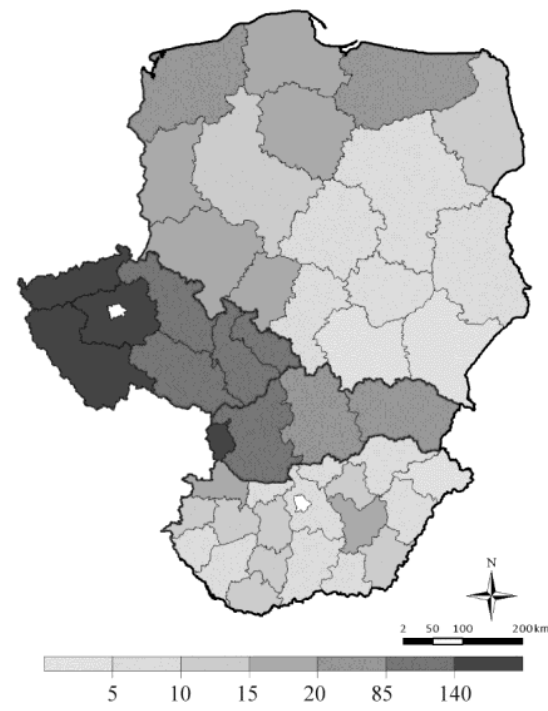

b) Regionális GDP, 2013 (euró/fö)

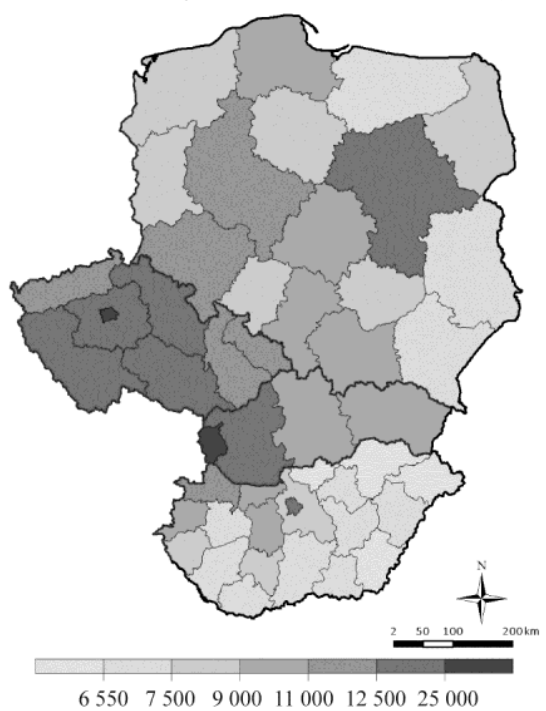

d) Munkaerö-felhasználás, 2013 (fö/100 hektár)

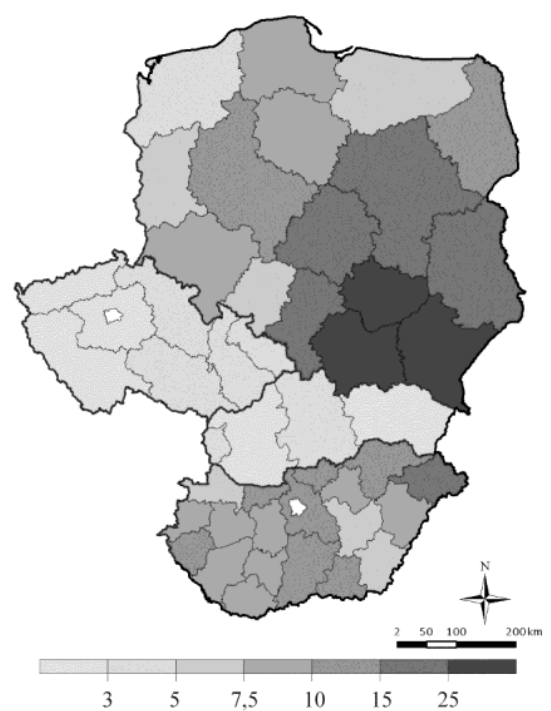

Forrás: A 3. táblázatban felsorolt adatbázisok, illetve az Eurostat [2016] alapján saját szerkesztés.

A visegrádi országok regionális statisztikái Magyarország esetében megyei (NUTS 3) szinten (összesen 19 regionális egység), Lengyelország esetében tizenhat 
vajdaságra, Csehországban és Szlovákiában pedig 7, illetve 4 régióra (NUTS 2) állnak rendelkezésre, melyek forrásai a földpiaci árak tekintetében a 3. táblázatban közzétett adatbázisok, míg a termőföld értékében mutatkozó térségi különbségeket magyarázó változók esetében az Eurostat regionális statisztikai adatai. Elemzésünkben nem szerepel azonban Budapest és Prága közigazgatási területe, melyekhez nem kapcsolható értékelhető termőföldforgalom. Ezek kihagyásával így a visegrádi országcsoporton belül összesen 46 önálló területi egység vizsgálatára nyílik lehetöség.

Regionális szinten a visegrádi országok körében a legmagasabb földárak Szlovákia nyugati részén, a pozsonyi régióban alakultak ki, ahol az egy hektárra vetített átlagos forgalmi érték 2015-ben 15300 euró volt. Viszonylag magas, 7500 és 15000 euró/hektáron keltek el a földek Közép-Csehországban, illetve Lengyelország nyugati és középső területein a Gdansk-Poznan-Wroclaw-Katowice közötti képzeletbeli vonal mentén. Legalacsonyabb volt az árszint Kelet-Szlovákiában, illetve Magyarország területén. A regionális GDP nagysága részleges egyezést mutat a földárakkal: Szlovákiában Pozsony és környéke, Csehországban a középső területek fejlettebbek az országos átlaghoz képest, míg Magyarországon az észak-dunántúli (Győr-Moson-Sopron, Vas, Fejér és Komárom-Esztergom) megyék gazdasági teljesítménye kiemelkedő. Lengyelországban az egy före jutó regionális GDP és a hektáronkénti termőföldár - a főváros, Varsó térségét leszámítva - közép-nyugaton, az alsó- és felső-sziléziai, valamint a nagy-lengyelországi vajdaságokban magasabb volt, mint a délkeleti, Ukrajnával szomszédos vajdaságokban (Eurostat [2016]).

Az átlagos birtokméret Csehországban mindenütt, Szlovákiában pedig a nyugati részen meghaladja a 85 hektárt. Lengyelországban a már korábban említett kettősség rajzolódik ki: a déli és keleti területeken, ahol 1989 előtt az állami gazdaságok szerepe elhanyagolható volt, 3 és 8 hektár közötti átlagos birtokmérettel máig meghatározók maradtak a kisgazdaságok. A balti partvidéken és a Németországgal határos vajdaságokban pedig egyszerre van jelen a családi tulajdonú kisbirtokrendszer és a privatizáció során átalakult állami nagyüzemek öröksége, így az egy gazdaság által megmüvelt terület átlaga 13 és 25 hektár között ingadozik, de a Nyugat-pomerániai vajdaság területén eléri a 28,7 hektárt is. Magyarország mezőgazdaságának birtokszerkezete ennél kisebb országon belüli eltéréseket mutat, az átlagos birtokméret a szántóföldi növénytermesztés által dominált Jász-Nagykun-Szolnok (16,8 ha), illetve Györ-Moson-Sopron megyében (16,2 ha) a legnagyobb. Ennél lényegesen szétaprózódottabb területekkel találkozhatunk a nagyüzemi szántóföldi gazdálkodás számára kevésbé kedvező domborzati és talajadottságokkal rendelkező SzabolcsSzatmár-Bereg (4,7 ha), Zala (5,7 ha), Borsod-Abaúj-Zemplén (7,5 ha) és Nógrád megyében (7,8 ha). Az adatok jól szemléltetik, hogy a visegrádi országcsoporton belül párhuzamosan három agrárgazdasági modell van jelen: 1. a szinte kizárólagosan nagybirtokokra épülő cseh és szlovák rendszer; 2. a Magyarországra és Lengyelország nyugati-északnyugati térségére jellemző vegyes birtokszerkezet, valamint 3. a 
Lengyelország déli és keleti vajdaságaiban müködő, családi tulajdonú kis- és közepes gazdaságok (Trendov [2016], Möllers-Buchenrieder-Csaki [2011]).

A mezőgazdaságban a mai napig jelentős az időszaki munkákhoz, különösen a tavaszi munkálatokhoz és a nyári-őszi betakaríáshoz kapcsolódó szezonális foglalkoztatás. Az agrárszektor által teremtett munkahelyek számának meghatározását tovább nehezíti, hogy a családi gazdaságokban számottevő szerepet játszik az önfoglalkoztatás, valamint a közeli hozzátartozók és az egyéb rokonok nem fizetett munkája. Ezek tudatában a munkaerő-felhasználást a szezonális foglalkoztatás, az önfoglalkoztatás és a családi munkaerő becsült értéke alapján, állandómunkahelyegyenértékes formában vesszük figyelembe (Eurostat [2016]). Ebből intenzitási viszonyszámként a munkaerő-felhasználást a művelt területek nagyságával elosztva kapjuk meg a 100 hektárra jutó munkaerö-állomány nagyságát. Országos léptékben a mezőgazdaság foglalkoztatásban betöltött szerepe Csehországban és Szlovákiában 2013. évi adatok alapján a teljes munkaerő-kereslet 3 százalékának felel meg, Magyarországon a mutató ennél magasabb $(4,8 \%)$, míg Lengyelországban kiemelkedöen nagy, 12 százalék (Chmielinski-Soliwoda [2015]).

A mezőgazdasági termelés munkaerő-intenzitása különösen Lengyelország déli és keleti vajdaságaiban kiugróan magas, tehát éppen azokon a területeken, ahol a kis kiterjedésű családi gazdaságok szerepe maradt meghatározó. A Kis-lengyelországi vajdaság területén a 100 hektárra jutó foglalkoztatás éves átlagban meghaladja a 33 fót, míg a vele szomszédos régiókon belül 15-30 fö/100 hektár között alakul. Ezzel szemben Nyugat-Pomerániában, ahol a leginkább jellemző a privatizált volt állami nagygazdaságok által folytatott szántóföldi növénytermesztés, a foglalkoztatás alig éri el a 100 hektáronkénti 4 fö állandómunkahely-egyenértéket. Csehországban és Szlovákiában a mezőgazdaság foglalkoztatásban betöltött szerepe régiós különbségeket nem mutatva, általánosságban véve alacsony, 100 hektár müvelt területenként 2 és 4 fö között mozog. A magyarországi adatok Lengyelország nyugati és északi térségeihez hasonlíthatók, a 100 hektárra jutó foglalkoztatás a szántóföldi növénytermesztéssel jellemezhető Jász-Nagykun-Szolnok és Győr-Moson-Sopron megyében 6 fő körül alakul, míg Komárom-Esztergom, Zala és Szabolcs-Szatmár-Bereg megyében 12 és 16 fő között. E megyékben jelentős az állattartás és a kertészeti ágazat szerepe, valamint számottevő a kis- és közepes birtokokon gazdálkodó családi agrárvállalkozások száma.

Az európai uniós agrárszektor-specifikus és általános gazdaságstatisztikai mutatók közül egyedi kapcsolatvizsgálat, modellszelekció, továbbá a keresztkorreláció-elemzés alapján a következők gyakorolnak számottevő, legalább 80 százalékos valószínűséggel igazolható hatást a termőföld értékében tapasztalható regionális különbségekre:

- a társas vállalkozásként müködő gazdaságok aránya az összes gazdaságon belül (\%),

- átlagos birtokméret (hektár), 
- 100 hektárra jutó munkaerő-felhasználás állandómunkahelyegyenértékben (fö),

- egy hektárra jutó STÉ (euró/hektár),

- regionális GDP (euró, nominális),

- közúthálózat sủrüsége (úthossz km/ 1000 km² terület).

A változók kiválasztása során azonban különös figyelemmel kell lenni az összefüggések irányára is. Ugyanis miközben a térségi mezőgazdasági, illetve (tágabb értelmezésben) a teljes regionális gazdasági aktivitás kétségkívül befolyásolja a földpiac keresleti viszonyait és az egységnyi termőföld termelékenységét, addig a földár önmagában nem valószínű, hogy számottevő hatást gyakorol az adott régió egy före jutó GDP-jére vagy a foglalkoztatás szintjére. Az előbb felsorolt változók felhasználásával a regionális termőföldárakra a következő lineáris regressziós modell illeszthető:

$$
y=\hat{\beta}_{0}+\hat{\beta}_{1} x_{1}+\hat{\beta}_{2} x_{2}+\ldots+\hat{\beta}_{6} x_{6}+\varepsilon,
$$

ahol $\hat{\beta}_{0}$ a regionális földár magyarázóváltozóktól független, konstans komponense, $\hat{\beta}_{1}, \hat{\beta}_{2}, \ldots, \hat{\beta}_{6}$ az előbb felsorolt prediktorok egységnyi változásának földárra gyakorolt hatása, $\varepsilon$ pedig a modell által nem magyarázott hibatag, azaz a becsült és a tényleges térségi földár közötti eltérés.

A vizsgálatba vont változók összegzett magyarázóerejét a modell többszörös determinációs együtthatójával fejezhetjük ki. E paraméter kiszámításának alapja az eredményváltozó - azaz a régiós termőföldátlagár - szórásnégyzet-összegének és a hibatagok négyzetösszegének egymáshoz képest mért aránya. Minél kisebb a hibatagok négyzetösszege, annál nagyobb az eredményváltozó szóródásának modell által magyarázott hányada. Az előbb ismertetett hat magyarázóváltozó 83,65 százalékban képes visszaadni a regionális hektáronkénti földárakban felfedezhetö különbségeket. Ez megfelelő eredmény, mivel a legalacsonyabb (Magyarország, Nógrád megye 1550 euró/hektár) és a legmagasabb (Szlovákia, pozsonyi régió, 15300 euró/hektár) térségi árszínvonalak közötti eltérés közel tízszeres.

A magyarázóváltozók közül öt valamennyi standard szignifikanciaszinten, míg az egy hektár müvelt területre jutó STÉ csak 80 százalékos valószínűséggel gyakorol hatást a regionális árkülönbségekre. E változó elhagyásával modellünk magyarázóereje a leggyakrabban alkalmazott szelekciós kritériumok alapján - például korrigált $R^{2}$, Akaike-féle kritérium - egyértelmüen romlana, így nem tekinthetünk el ennek az agrárszektor-specifikus mutatónak a használatától sem. A magyarázóváltozóktól független, konstans árkomponens negatív, -411 euró, azonban ez a becslés magas standard hibája miatt nem különbözik szignifikánsan a zérus értéktöl, melyre a relevanciavizsgálat során kapott 0,63 -as $p$-érték is utal. 
5. ábra. A regressziós modell által becsült és a tényleges földár kapcsolata a visegrádi országok 46 vizsgált régiójában, 2013-2015

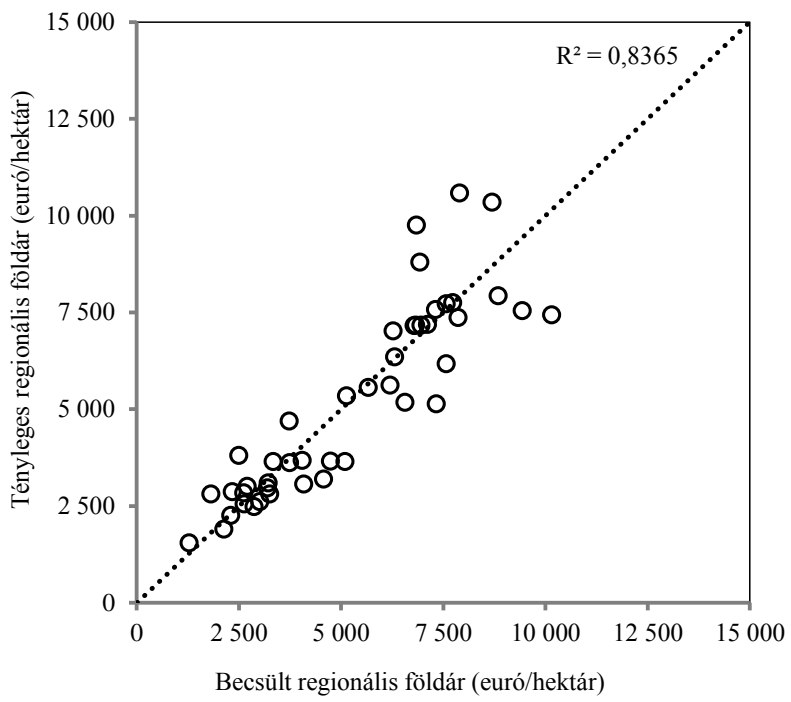

Forrás: A 3. táblázatban felsorolt adatbázisok, illetve az Eurostat [2016] alapján saját szerkesztés.

7. táblázat

A termöföld piaci árának regionális különbségeit magyarázó változók

\begin{tabular}{|c|c|c|c|c|c|c|}
\hline Megnevezés & $\begin{array}{c}\text { Koefficiens } \\
(\beta)\end{array}$ & $\begin{array}{l}\text { Standard } \\
\text { hiba }\end{array}$ & $p$-érték & $\begin{array}{l}\text { Szignifikancia- } \\
\text { szint }\end{array}$ & $\begin{array}{l}\text { Parciális } \\
\text { hatás }\end{array}$ & VIF \\
\hline Konstans árkomponens (euró) & -411 & 853,1 & 0,63 & - & - & - \\
\hline $\begin{array}{l}\text { Társas vállalkozásként müködő } \\
\text { gazdaságok aránya az összes } \\
\text { gazdaságon belül }(\%)\end{array}$ & $-424,6$ & 134,4 & 0,0031 & $* * *$ & 9418 & 13,51 \\
\hline Átlagos birtokméret (ha) & 36,82 & 10,96 & 0,0017 & $* * *$ & 5789 & 8,70 \\
\hline $\begin{array}{l}\text { Száz hektárra jutó munkaerō- } \\
\text { felhasználás* (fö) }\end{array}$ & $-114,3$ & 40,8 & 0,008 & $* * *$ & 3623 & 2,252 \\
\hline $\begin{array}{l}\text { Egy hektárra jutó standard termelé- } \\
\text { si érték (euró/hektár) }\end{array}$ & 1,179 & 0,910 & 0,20 & - & 1665 & 2,387 \\
\hline Regionális GDP (euró/fö) & 0,364 & 0,087 & 0,0002 & $* * *$ & 10465 & 4,219 \\
\hline $\begin{array}{l}\text { Közúthálózat sürüsége } \\
\text { (úthossz km/1000 km² terület) }\end{array}$ & 2,665 & 0,510 & 0,000006 & $* * *$ & 5204 & 1,965 \\
\hline
\end{tabular}

* Állandómunkahely-egyenértékben.

Megjegyzés. VIF (variance inflation factor): varianciainflációs tényező. *** $p=0,01$ szinten szignifikáns.

Forrás: A 3. táblázatban felsorolt adatbázisok, illetve az Eurostat [2016] alapján saját számítás. 
A vizsgálatba vont változók közül a regionális földár szignifikánsan pozitívan reagál a birtokméret növekedésére; egy hektárnyi növekedés közepes becslés (a többváltozós lineáris regresszió által becsült meredekségi koefficiens) szerint 36,8 euróval, 95 százalékos valószínűséggel 14,7 és 59,0 euró közötti mértékben emeli a termőföld fajlagos piaci értékét. Az egy före jutó regionális GDP egy eurónyi növekedése és a burkolt közúthálózat $1000 \mathrm{~km}^{2}$-re jutó hosszának emelkedése is pozitív hatással bír: előbbi egységenként 0,19-0,54 euró/hektár, utóbbi pedig 1,6-3,7 euró/hektár áremelkedéssel társítható. Az egy hektárra jutó mezőgazdasági STÉ és a földár között 80 százalékos valószínűséggel mutatható ki összefüggés, 1,0 eurós termelékenységnövekedés közepes becslés szerint 1,18 euró termőföldáremelkedéshez vezet. A negatív hatást gyakorló változók között találjuk a társas vállalkozások régión belül müködő, összes gazdasághoz viszonyított arányát. Ha az egy százalékponttal nő, a termőföldek forgalmi értéke várhatóan 425 euróval csökken. Azokban a térségekben, ahol magas a mezőgazdaságon belüli munkaerőfelhasználás, általában alacsony a termőföld hektáronkénti ára. Ez azzal magyarázható, hogy a magas agrárszektorbeli foglalkoztatás olyan területekre jellemzö, ahol föként családi gazdaságok folytatnak mezőgazdasági termelőtevékenységet, továbbá jelentős az állattartással és a kertészettel foglalkozó gazdaságok súlya. Minél munkaintenzívebb kultúrákra szakosodott egy-egy térségben a termelés, annál kevésbé mutatkozik igény a gazdák körében birtokuk méretének növelésére, ami keresleti nyomás útján kiválthatná a helyi földárak emelkedését.

A változók parciális hatásával azt mérjük, hogy egy paraméter változása a mintában előforduló legkisebb értékről a legnagyobbra abszolút értelemben mekkora különbséget képes magyarázni az eredményváltozóban észlelt eltérésekből. A visegrádi országcsoporton belül a legalacsonyabb és a legmagasabb regionális termőföldárszínvonalak közötti eltérés egy hektárra vetítve közel 13800 euró volt, amit egyik magyarázóváltozó sem képes önállóan leírni. A legnagyobb parciális hatással rendelkező regionális GDP/fö mutatóhoz is csak 10465 euró/hektár árkülönbség kapcsolható, ezzel szemben a legkisebb „befolyással rendelkező” magyarázóváltozók parciális hatása csak 1600 és 3600 euró/hektár közöttire tehetö. A VIF, mely a magyarázóváltozók közötti keresztkorrelációs összefüggésekből adódó multikollinearitás szintjét méri, egy kivétellel valamennyi változó esetében az elfogadható, 10 alatti tartományban van. A társas vállalkozásként müködő gazdaságok számának összes gazdasághoz viszonyított aránya és az átlagos birtokméret közötti számottevő korreláció az oka annak, hogy ebben az esetben a VIF szintje meghaladja a korábban említett küszöbértéket. E változó elhagyását azonban nem látjuk indokoltnak, mert ez a modell magyarázóerejét, azaz a többszörös determinációs együtthatóját önmagában közel 5 százalékponttal csökkentené. 


\section{5. Összegzés}

A termőföld mint erőforrás számos egyedi tulajdonsággal rendelkezik. Ideális körülmények között - a tőkejavak többségével ellentétben - nem amortizálódó termelőeszközröl van szó, melynek helyi és globális kínálata rögzített, kereslete azonban számos tényező együttes függvénye.

A termőföld árának alakulását jelen tanulmányban közgazdasági megközelítésböl vizsgáltuk, mely szerint a föld értéke minden esetben a birtoklásából származó nettó jövedelmek végtelen sorozatának jelenértékével egyenlö. Több forrás felhasználásával összeállított kimutatásaink alapján a földárak a visegrádi országokban 2000 és 2015 között a nyugat-európai árszínvonal irányába konvergáltak, e folyamat a 2004. évi európai uniós csatlakozást követően a korábbinál is markánsabban jelentkezett. A négy ország földpiaci ármozgásai a külső sokkhatásokra (például a 2008-2009-es globális pénzügyi és gazdasági válságra) jóval kevésbé voltak érzékenynek a lakóingatlanok és az ipari-kereskedelmi létesítmények piacához képest. A földalapú befektetések hozamai a vizsgált időszakban meghaladták az inflációs mutatók (GDPdeflátor, fogyasztói árindex) másfél évtizedes átlagértékeit. Kiemelendő, hogy a 2008-2009-es válságot követő években Lengyelország és Magyarország földpiacán egyáltalán nem volt megfigyelhető a hozamok csökkenése, ami arra utal, hogy a termőföldre a piaci szereplők - például a nemesfémekhez hasonlóan - krízisidőszakban is értékálló befektetésként tekintenek.

Az elmúlt másfél évtizedben a leggyorsabb (éves átlagban 13,8 százalékos) termöföldár-emelkedés Lengyelországban következett be, ezt követte Szlovákia és Magyarország évi 7,3-7,4 százalékos, majd Csehország évi 4,6 százalékos átlagos értéknövekedéssel. Az országcsoporton belül is megfigyelhető volt az árak konvergenciája. A legkisebb mértékủ emelkedés Csehországban következett be, ahol 2000 körül a másik három visegrádi országnál lényegesen magasabbak voltak az árak. A termöföldek árszínvonala közötti relatív szórás a visegrádi négyekben tizenöt év leforgása alatt a 60-80 százalékos szintről 40 százalékra, a legalacsonyabb és a legmagasabb árszínvonal közötti eltérés pedig négyszeresről háromszorosra csökkent. A földforgalom jogi szabályozásában fennálló különbségek az országcsoporton belül jelentősnek mondhatók. Miközben a külföldi magánszemélyek földvásárlását valamennyi visegrádi ország korlátozni igyekszik, a jogi személyek és a külföldi tulajdonban levő, jogi személyiséggel rendelkező gazdasági társaságok földvásárlási jogosultságának szabályozásában számottevő eltérések tapasztalhatók. Utóbbi téren a leginkább megengedő a szlovák állami szabályozás, míg legkevésbé a magyar földforgalmi törvény, mely a külön nevesített kivételektől eltekintve, jogi személyek számára nem teszi lehetővé termőföld tulajdonjogának megszerzését. Ugyan a vizsgált időszakban jogszabályi háttérre is visszavezethető, országspecifikus földpiaci sajátosságok voltak észlelhetők 
- például a szlovákiai árbuborék kialakulása 2006 és 2009 között -, a földforgalmi szabályozás országonként eltérő volta önmagában nem tekinthető elegendőnek a termőföldpiacon tapasztalható különbségek magyarázatához.

A nemzeti szintủ mutatók eltérései mellett jelentősek a regionális szintű különbségek is a visegrádi országokon belül. Az általunk vizsgált hat, agrárszekort jellemzö, általános gazdasági változó ezeket a 2015. évre nézve 83,7 százalékban képes magyarázni. A térségekre jellemző átlagos birtokméret, hektáronkénti termelékenység, GDP-szint, illetve közúthálózat-fejlettség pozitívan, míg a társas vállalkozások összes mezőgazdasági termelőhöz viszonyított aránya, valamint a 100 hektárra jutó munkaerö-felhasználás negatívan hat a helyi termőföldárakra. A vizsgálatba vont változók közül a helyi gazdaság egészének relatív fejlettségét mérő mutatók (például a regionális GDP) földárra gyakorolt parciális hatása meghaladja az agrárszektorspecifikus paraméterek, például az egy hektárra jutó mezőgazdasági termelés hatását. Az ismert közgazdasági összefüggések alapján, a termőföld rögzített kínálatából, a világ népességének lassuló, de folyamatos emelkedéséből, az egyre nagyobb élelmiszerigény által indukált többletkeresletből és a hektáronkénti termelékenység növekedéséből adódóan a visegrádi országokban a földárak további emelkedésére számíthatunk. A jövőben legnagyobb mértékủ áremelkedés Magyarországon várható, ugyanis megközelítőleg azonos általános gazdasági fejlettség mellett a földpiacon tapasztalható árak itt a legalacsonyabbak.

\section{Irodalom}

Bastian, O. - SchreIBER, K.-F. [1999]: Analyse und ökologische Bewertung der Landschaft. 2. Neubearbeitete Auflage. Spektrum Akademischer Verlag. Heidelberg, Berlin.

Biospotrebitel [2016]: Polnohospodárska poda predaj. http://www.biospotrebitel.sk/inzercia/ rubrika/polnohospodarska-poda-predaj.htm

BODENVERWERTUNGS- UND -VERWALtungs GMBH [2016]: Verkäufe von Agrarland. http://www.bodenmarkt.info/g/BM-Ex/3-1/3-1.html

Buday, S. - GrausovÁ, G. [2015]: Trh s pódou a nájom pol'nohospodárskej pódy na Slovensku. Mezinárodní konference „Udržitelný rozvoj krajiny s využitím nástrojů pozemkových úprav a agroekologických systémů”. 16-17 června. Staré Splavy.

BurgERNÉ G. A. [1997]: A mezőgazdasági föld vételára és bérlete. Statisztikai Szemle. 75. évf. 1. sz. 28-44. old.

BuRgERnÉ G. A. [2002]: A mezögazdasági földtulajdon és földbérlet. Akadémiai Kiadó. Budapest.

ChMielinski, P. - SoliwodA, M. [2015]: Dilemmas of development of agriculture and rural areas in the countries of the Visegrad Group. XIII. European Rural Development Network Conference. 18-21 October. Zakopane.

CHRZANOWSKA, M. [2016]: Spatial analysis of agricultural land prices by regions in Poland. Proceedings of the 2016 International Conference "Economic Science for Rural Development" No. 42. LLU ESAF. Jelgava. pp. 30-37. 
CsAKI, Cs. - JAMBOR, A. [2013]: The impacts of EU accession on the agriculture of the Visegrad countries. Society and Economy. Vol. 35. Issue 3. pp. 343-364.

DovRING, F. [1987]: Land economics. Breton Publishers. Boston.

ERDÉLYI T. [2009]: Földtulajdon és földbirtokviszonyok alakulása az EU tagországokban. Doktori értekezés. Szent István Egyetem. Gödöllö.

EuRostat [2016]: Statistical Database. http://ec.europa.eu/eurostat/data/database

FAOSTAT (Food And Agriculture Organization of the United Nations) [2016]: Food and Agriculture Data. http://www.fao.org/faostat/en/\#home

FHB (FHB JELZÁLOGBANK NyRT.) [2015]: Termöföldindex 2015 - Folytatódott az áremelkedés a földpiacon. http://www.fhbindex.hu/FHB-Index/FHB-Termofoldindex

GUS POLAND [2015]: Rocznik statystyczny rolnictwa i obszarów wiejskich 2014. Glówny Urzad Statystyczny. Warsaw.

HERBST Á. - ORLOvits Zs. [2005]: A termőföldtulajdon és -használat szabályozása. In: Herbst Á. Szabóné Willin E. - Uzonyi Gy. (szerk.): Magyar gazda Európában. RAABE Kiadó. Budapest. 10-16. old.

HypoteCNí BANKA [2016]: HB Index - Silná poptávka zvyšuje ceny nemovitostí. https://www.hypotecnibanka.cz/o-bance/pro-media/hb-index/silna-poptavka-zvysuje-cenynemovitosti/

KELEMEN K. [2007]: „Fából-vaskarika”. Kisérletek a földpiac-földár pótlására 1945-től az ezredfordulóig Magyarországon. Doktori értekezés. Pázmány Péter Katolikus Egyetem. Budapest.

Knoll, K. - Schularick, M. - Steger, T. [2015]: No Price Like Home: Global House Prices, 1870-2012. CESifo Working Paper Series No. 5006. Center for Economic Studies \& Ifo Institute. http://www.cesifo-group.de/portal/page/portal/DocBase_Content/WP/WP-CESifo_Working _Papers/wp-cesifo-2014/wp-cesifo-2014-10/cesifo1_wp5006.pdf

KSH (KöZPonti StatisztiKai Hivatal) [2015]: Mezögazdasági termöföldárak és bérleti díjak, 2014. Statisztikai Tükör. 81. sz. November 25. https://www.ksh.hu/docs/hun/ xftp/stattukor/mgfoldarak/mgfoldarak14.pdf

MAGDA R. - SzŰCS I. [2002]: Új irányzatok a földhasznositásban. Agroinform Kiadó. Budapest.

Magyar Közlöny [2013]: 2013. évi CXXII. törvény a mező- és erdőgazdasági földek forgalmáról. 111. sz. 63137-63160. old. http://www.kozlonyok.hu/nkonline/MKPDF/hiteles/MK13111.pdf

MAPIO.CZ [2016]: Prodej pozemku - Stredni Cechy, Jihozápad, Severozápad, Severovychod, Jihovychod, Stredni Morava, Moravskoslezsko. http://mapio.net/okoli/84341324-1-3-0a/?page $=1$

Möllers, J. - BuchenRIeder, G. - CsAKI, C. [2011]: Structural Change in Agriculture and Rural Livelihoods: Policy Implications for the New Member States of the European Union. IAMO Studies on the Agricultural and Food Sector in Central and Eastern Europe. Vol. 61. Halle.

NAÁRNÉ T. Zs. [2006]: A földértékelés gyakorlata az Európai Unióban. Gazdálkodás. 50. évf. 16. sz. 114-118. old.

NAÁRnÉ T. Zs. [2009]: A termőföld közgazdasági értéke és piaci ára. Agroinform Kiadó. Budapest.

OTP JelZÁlogBank [2011-2016]: OTP Termöföld Értéktérkép 2011-2016. https://www.otpbank.hu/OTP_JZB/online/A0600000000.jsp

PATOCSKAI Z. [2012] Az erdészeti és a mezögazdasági földértékelési rendszer ökológiai alapjainak összehasonlitása, az egységesités lehetséges módjai. Doktori értekezés. Nyugat-Magyarországi Egyetem. Sopron. 
PiketTy, T. [2014]: Capital in the Twenty-First Century. Harvard University Press. Cambridge. http://doi.org/10.4159/9780674369542

RicARDo, D. [1817]: On the Principles of Political Economy and Taxation. John Murray. London.

SogAard, V. [1993]: The land market cycle. European Review of Agricultural Economics. Vol. 20. Issue 1. pp. 65-76. http://doi.org/10.1093/erae/20.1.65

Storie, R. E. [1933]: An Index for Rating the Agricultural Value of Soils. Bulletin No. 556. California Agricultural Experiment Station. Berkeley.

StreleceK, F. - Lososova, J. - ZdeneK, R. [2009]: Comparison of subsidies in the Visegrad Group after the EU accession. Czech Agricultural Economics. Vol. 55. No. 9. pp. 415-423.

SzÜCS I. [1998]: A föld ára és bére. Agroinform Kiadó. Budapest.

SzÜCS I. [2003]: A termőföld közgazdasági értékelése. In: Gaál Z. - Máté F. - Tóth G. (szerk.): Földminösités és földhasználati információ. Veszprémi Egyetem. Veszprém. 261-272. old.

TAKÁC, I. - BANDLEROVÁ, A. [2010]: The agricultural land prices and land transactions development in Slovakia and selected EU countries. Slovenská pol'nohospodárska kniznica pri SPU. Nitre. http://www.slpk.sk/eldo/2010/zborniky/015-10/s2/takac_bandlerova.pdf

Trendov, N. [2016]: CAP Performances of the Visegrad Countries After Accession to European Union. Think Visegrad - V4 Think Tank Platform. https://think.visegradfund.org/wpcontent/uploads/IVF-Paper-Trendov-final.docx

VRbovÁ, E. - NeMEC, J. [2005]: Land market development in the Czech Republic. Czech Agricultural Economics. Vol. 51. No. 5. pp. 216-220.

\section{Summary}

Twelve years after the Visegrad countries' accession to the European Union, the question of whether total price convergence can be achieved between the land market of new and old member states remains open. Over the past decade and a half, the agricultural land market of the new East European accession states could have been characterized by quite a vivid turnover of land and also a dynamic increase of market prices compared to the inner market of old EU members. Present study aims at exploring and analysing in detail the main drivers of the latter tendency. The authors present the overall effect of different production structures, land market regulation and macroeconomic tendencies on agricultural land prices of the Visegrad countries. Besides dealing with the countrywide changes and some underlying reasons, they find explanations for the difference in value emerging on regional and county-provincial levels. Regarding the fact that agricultural land supply and demand are strongly connected to fixed locations, regional price changes are reproduced by creating a multiple linear regression model composed of indicators expressing the local development of the agricultural sector and the entire economic system. 